\title{
Modern Military Rifles
}

\section{Major the Hon. T. F. Fremantle}

To cite this article: Major the Hon. T. F. Fremantle (1905) Modern Military Rifles, Royal United Services Institution. Journal, 49:330, 879-934, DOI: 10.1080/03071840509416604

To link to this article: http://dx.doi.org/10.1080/03071840509416604

\section{曲 Published online: 11 Sep 2009.}

Submit your article to this journal

Џll Article views: 9

Q View related articles $₫$ 


\title{
MODERN MILITARY RIFLES.
}

\author{
By Major the IIon. T. F. FREMANTLE, 1st Bucks V.R.C.
}

\author{
Tuesday, 28th March, 1905. \\ Major-General Sir Thomas Fraser, K.C.B., C.M.G., late R.E., \\ in the Chair.
}

THE subject which I have undertaken is a very large one, and one not to be exhausted within the limits of a paper. It offers endless points, both of detail and of principle, to be considered. Its aspects are many and various: historical, theoretical, practical. There is primarily the point of view of the infantryman and the cavalryman; there is also that of the engineer, the chemist, the sportsman, and the expert marksman. And it has to be remembered that the outcome in concrete form of all these views is necessarily a compromise upon which; from one or other point of view, it is almost certain that improvement will be possible.

\section{LENGTH OF RifLe.}

Let us take first the dimensions of the rifle. It must be noted that the interposition of a breech action between the small of the butt and the barrel tended to reduce the length of barrel of the breech-loader, as compared with the muzzle-loader. Similarly, the adoption of the box magazine and the bolt action still further curtailed the barrel. A similar change took place in the weapons of all nations.

The first breech-loading rifle of the British Arny was the Snider. This had a leugth of 4 feet 7 inches, and, with its bayonet fixed, measured half an inch over 6 feet. The Mrartini-Henry, though $5 \frac{1}{2}$ inches shorter than the Snider, had a long bayonet, so that it was only 1 inch sharter ( 5 feet $11 \frac{1}{2}$ inches) with the bayonet attached. The 303 , of the same length as the Martini-Heury ( 4 feet $1 \frac{1}{2}$ inches), with the bayonet fixed was actually 10 inches shorter (5 feet $1 \frac{1}{2}$ inches). The length of rifle and bayonet, is a subject on which I hope to touch later.

The L.-E. short rifle, with butt of normal (i.e., medium) length, measures 3 feet 8 inches . without, and 4 feet 83 inches with its bayonet. It is a curious fact that reduced length and weight should be more important to the mounted man, whose horse carries both himself and his weapons, than to the foot soldier. Opinion is much divided as to the best means of attaching the rifle on horseback. The solution of this problem may well have a bearing on the proportions of the rifle to be carried.

vot. xLIX. . 
Ingenious attempts have been made to combine a 30 -inch barrel with a reduction in the length of the whole rifle, by Mr. Thornycroft and Major Godsal. This is effected by altering the action so that it and the bolt are set back and the length of butt behind them reduced, and it entails certain modifications to meet the necessary curvature of the stock. These rifles are necessarily still in the experimental stage.

\section{IVEIGHT.}

The more elaborate brecch and magazine mechanism tended to an increase rather than to a reduction of weight. Owing to the weight and clumsiness of the long rifle on horseback, we, in common with other nations, armed our mounted troops with a carbine, weighing nearly 2 lbs. less than the rifle, and 91 inches shorter. The failure of the carbine in a recent war, in which there was much work at long ranges, is a matter of history. Handiness and lightness go together in the main, though the question of the balance of the weapon is an important one. The weight of the bolt action has tended to throw back the centre of gravity of modern rifles, as compared with older patterns, making them, on the whole, handier. As regards weight, it is obviously undesirable that the soldier should carry a heavier arm than is necessary. Weight saved in the arm can be added to the ammunition carried. In addition to this, the strain on the soldier seems to be heavier than formerly. We read of battles continued day after day, and of the fighting man's power of physical and nervous endurance being taxed up to or even beyond its limit. Whether in such fighting or on prolonged marches every ounce of weight must be a consideration.

What, then, are the factors limiting the lightness of a military rifle? First, that it should be amply strong enough to stand rough usage of all kinds, as well as the strain of bayonet fighting. The long fore end, band, and nose-cap add much to the weight of the arm as compared with a rifle of similar power made for the sportsman. The Boers in many cases cut away the greater part of the fore end of their Mausers, not needing to use the bayonet.

The second factor tending to kecp up the weight of military arms is the reccil. This is more important than formerly, because in modern war a very large number of shots may have to be fired in a day. The velocity of recoil and the energy which has to be absorbed by the shoulder are reckoned to be for various British rifles as follows:-

\begin{tabular}{|c|c|c|c|c|}
\hline - & & Teight. & Velocity of recoil. & Energy of recoil. \\
\hline $\begin{array}{l}\text { Snider ... } \\
\text { Martini-Ïenry } \ldots \\
\text { Lee-Enfield } \\
\text { L.-E. Short Rifle }\end{array}$ & \begin{tabular}{l|}
$\cdots$ \\
$\cdots$ \\
$\cdots$ \\
$\cdots$
\end{tabular} & $\begin{array}{cc}\text { lbs. } & \text { ozs. } \\
9 & 1 \\
9 & 0 \\
9 & 4 \\
8 & 2 \frac{1}{2}\end{array}$ & $\begin{array}{c}\text { Feet per second. } \\
12 \cdot 05 \\
13 \cdot 85 \\
9 \cdot 19 \\
10 \cdot 37\end{array}$ & $\begin{array}{c}\text { Ft.-lbs. } \\
20 \cdot 42 \\
26 \cdot 81 \\
11 \cdot 9 \\
13 \cdot 4\end{array}$ \\
\hline
\end{tabular}

The energy of recoil of an ordinary shot-gun of $7 \mathrm{lbs}$. weight is about $24 \mathrm{ft} .-1 \mathrm{bs}$; that of the U.S.A. short rifle is $18.33 \mathrm{ft} .-\mathrm{lbs}$.

The increased energy of recoil of the $\mathrm{I}_{\text {L.-E. }} \mathrm{E}$. short rifle is, then, about 12 per cent. more than that of the I.ee-Enfield, and it is just about half that of the Martini-Henry. 
Energy of recoil is not synonymous with the blow felt by the shoulder, but with rifles of similar type it will serve as something of a general guide. It is not the least of the virtues of the modern small-calibre rifles that their kick is insignificant in comparison with that of such rifles as the Martini-Fenry.

The weights of modern infantry rifics are as follows:-

\begin{tabular}{|c|c|c|c|c|c|c|}
\hline & & & & & & lbs. \\
\hline Portugal & - & - & - & - & & 10 \\
\hline Switzerland & - & - & - & - & & 9 \\
\hline Denmark & - & - & - & - & & 9 \\
\hline Hollaud & - & - & - & - & & 9 \\
\hline Spain & - & - & - & 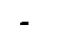 & & 9 \\
\hline Great Brit & ain & (L.-E & .). & - & - & 9 \\
\hline France & - & - & - & - & & 9 \\
\hline 'Turkey & & & & & & \\
\hline United Stat & es, & $1898\}$ & $\begin{array}{c}- \\
-\end{array}$ & - & & $y$ \\
\hline Germany & - & - & - & - & & 9 \\
\hline Russ & - & - & - & - & & 8 \\
\hline Roumania & - & - & - & - & & 8 \\
\hline $\begin{array}{l}\text { Japan } \\
\text { Belgium }\end{array}$ & & - & $\begin{array}{l}- \\
-\end{array}$ & - & & \\
\hline Italy & & - & - & - & & 8 \\
\hline Austria & - & - & - & - & & \\
\hline Great Brita & & ג.E. & 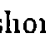 & (ifle) & & \\
\hline
\end{tabular}

The new short rifle of the United States weighs $8 \mathrm{lbs} .15 \mathrm{oz}$; it is therefore only 2 oz. lighter than the Krag-Jorgensen rifle, pattern 1898, which it is designed to supersede. It is understood that the manufacture of this short rifle is not being proceeded with, pending further trials against a modified long rifle. Switzerland has a short rifle weighing 8 lbs. $\frac{1}{2}$ oz., with which certain special troops are armed for work in the mountains. It is only sighted to 1,200 yards, and occupies a position midway between rifles and carbines.

Actions.

Bolt actions, now universal for military rifles, are rapid in working, simple, and safe, though it took many years to make them so. There is in nearly all of them a strong family likeness. The more solid the forward part of the bolt and the further forward the lugs which take the strain of the explosion, the stronger will be the action. The action of our Service rifle has the lugs so far back as to put under strain a considerable length of the bolt and the body, and it is much less strong than most modern actions. Nevertheless, it has accomplished much useful work in war. The actions of the Danish and United States (1898 pattern) Krag-Jorgensen rifles have only a single resisting lug. A weak action necessarily limits the pressures which can be permitted, and so limits the power of the cartridge. The action of the $\cdot 303$ is perfectly capable of withstanding a pressure of more than 20 tons to the inch; but for military purposes it is necessary to allow: a considerable margin in case of an accidental rise of pressure. Consequently, the working pressure is usually kept some 20 or 25 per cent. within the limit of safety. Figures stating pressure must be taken with reserve, but it would seem that our own rifle shares with those of Portugal (1886) and Dennark (1889) the distinction of having pres 
sures less than 16 tons. The working pressure for our long rifle is $15 \frac{1}{4}$, and for the short rifie $15 \frac{3}{4}$ tons. Other nations are credited with much higher pressures: 'l'urkey, Austria, and Belgium, with over $19 \frac{1}{2}$ tons; Germany, with 21 ; and Spain, with $22 \frac{1}{4}$, according to the Official Text Book of Small Arms, 1904. The last figure is no doubt much exaggerated; but actions can be made to stand such pressures safely. The new U.S.A. short rifle is designed for a normal pressure of 20 tons, and its bolt has 3 Iugs right forward instead of the 2 which are provided in nearly all actions. This action was tested with cartridges loaded to give 29 tons, which it stood perfectly. With one designed to give 45 tons the cartridge case and the extractor were broken, and the chamber slightly bulged, but the bolt held well. There is thus no difficulty, from the point of view of the strength of a well designed action, in making use of working pressures fully 25 per cent. higher thain those of our Service cartridge. .

If the lugs of the bolt do not bear equally upon the shoulders taking the resistance, a twist is given to the action under the strain of the explosion, and the direction in which the bullet is discharged will be affected. Special care therefore must be given to the fitting of the lugs. The single lug of the Krag action, already alluded to, must necessarily set up undesirable vibrations on firing.

Straight Pull Actions.-There is no difficulty in designing actions in which by a direct backward movement of the bolt, the lugs are first unlocked, and then the whole bolt drawn backwards. Austria has such a bolt in her rifle of 1895 , and Switzerland another, dating from 1889. The Lee action adopted in 1898 for the United States Navy rifle (a pattern very shortly afterwards discarded) worked backwards and forwards without turning, though it was neither a straight pull nor a bolt action. The Ross rifle, recently adopted by Canada, has a straight pull. But it is evident that the greater simplicity of the turning bolt, and the ease with which it can be made to give a powerful primary extraction, are generally thought to be points of high importance. The chief recommendation of the straight pull action is its greater rapidity. But it is known to anyone who is in the habit of handling magazine rifles, that the two motions of the ordinary bolt-the forward motion to close, and the turning motion to lock-are combined by the practised hand into one motion, taking only infinitesimally longer than the single straight motion. This loss of time is so small as to be almost immaterial when compared with the time occupied in aligning the rifle, even in rapid. fre. Straight pull actions are easier to reload withont taking the rifle down from the shoulder than those with turning bolts, while the sleevo helps to protect the bolt from dirt. But the general practice of nations is not in favour of the straight-pull bolt.

The Cut-Off.-The balance of practice is very decidedly against. the addition of a cut-off to the rifle, Denmark, France, Portugal, Turkey, and the United States alone liaving it: The British Navy still think it desirable. The explanation of its unpopularity probably lies in the objection to having to teach two metlods of loading, one. through the magazine, and the other directly into the chamber.

The Safety Bolt.-This is in general use, the exceptions being the rifles of Denmark, France, and Portugal, all comparatively old patterns. The Lee-Metford had no safety bolt; but one was adopted 
for the Lee-Enfield. The safety bolt of the L.E. short rifle is a reversion to an earlier pattern, and is lighter and more compact. It is actuated by the thumb, and lies on the left-hand side of the bolt, being pivoted on the aperture sight axis.

The Trigger I'ull. - In the I.-E. short rifle, the double or draw pull, universally in use in Continental rifles, has been adopted. It has decided advaniages, though it feels awkward to fingers accustomed to the ordinary pull-off. It enables a safe margin of weight to be combined with a comparatively delicate release, and it is one of the matters in which it would seem that we have been wise to adopt the Continental practice.

\section{Magazines.}

The tube magazine having been almost universally superseded by the box magazine, there are still various forms of the latter. The upright box miagazine is either narrow and deep, suitable for the single column of cartrilges inserted with their clip, or it is adapted for a double row of cartridges, lying alternately right and left, as in our own rific. Such a magazine is suitable for charger loading. In the Mondragon rifle of 5 -nm. bore, a clip is used containing the cartridges in a double column, but this system is still in the experimental stage.

Another class of box magazine is that which has its platform and spring controlled by a lever in the fore-end, so that the magazine can be filled with loose cartridges as required, the pressure of the spring being relieved, and the cartridges poured into it or put in singly.

An analogous magazine is the horizontal box of the $\mathrm{Krag}$ Jorgensen rifles, in whicl the cartridges are inserted, either singly or several at a time, through a trap door in the side of the rifle under the bolt. When the trap door is opened, the magazine spring is put out of action; when it is closed, the cartridges are pressed upwards, so as to engage with the bolt when drawn back.

Another variety of magazine is that in which the cartridges are stripped from the charger into a revolving receptacle, as in the Mannlichor-Schoenauer. This is an extremely neat magazine of recent introduction, and has not been adopted by any Power.

It follows from what has been said that magazines for a charger system are more compact, in proportion to the number of cartridges which they hold, than those containing clips. The Lee-Enfield magazine contains 10 cartridges, and the use in connection with it of a charger holding 5 seems an admirable arrangement. The magazine of the Swiss rifle holds 12 cartridges, and the charger used with it loolds 6 . The clip of the Italian rifle also holds 6 cartridges, but otherwise 5 is the'rule for all nations. The larger the number, the greater is the risk of jamming.

The balance of modern opinion inclines towards chargers rather than clips, and this in part for the reason that a clip-magazine must have an opening-in the bottom, to allow the clip to fall out, and is therefore liable to the intrusion of dirt, etc.

Clips or chargers necessarily form an addition to the weight as well as the bulk of the ammunition to be carried. The addition to the weight varies from 7 to 14 per cent.; that of the British chargers is 9.3 per cent. 
The various systems which have been invented for carrying the cartridges in bunches of 5 or otherwise, not connected together, and dropping them into the magazine by hand as required, have, so far, not met with much favour. The general opinion evidently is, that clips or chargers are well worth the additional weight which they entail. When a packet is handled, there is cortainly less liability to spill or to fumble in loading, than in dealing with a handful of loose cartridges. When we consider the great waste of ammunition in the war in South Africa, due to cartridges spilt or left on the ground, it is evident that the prevention or diminution of such waste must add directly to the efficiency of an army. Such matters as the pattern of bandoliers or pouclies, things outside the scope of the present lecture, are of the greatest importance.

\section{Amsinition.}

Light weight and small bulk are in some respects the most important qualities of small arm cartridges. The number of rounds which cau be packed in a given space is of great importance in considering anmunition supply. The necessity of packing the cartridges so that they can be put straight into the magazine without rearrangement, has necessarily made obsolete the old system of laying them head and tail, compact as that was. Cartridges having rims take up more room in packing and in a magazine than rimless ones. In addition to this they are more liable to jam in feeding into the chambers, as, if the rim of the top cartridge is behind that of the next cartridge underneath it, it is not free to move forward.

It has been objected to rimless cartridges, that they have nothing but the taper at the neck to prevent their being forced too far forward into the chamber. They are, however, held by the extractor hook, and they do not seem in practice to cause any difficulty. The Japanese have adopted a cartridge case, grooved for the extractor, having also a very narrow rounded rim projecting enough to give a bearing in the chamber, but not enough to prevent one cartridge sliding over another in feeding up into the magazine. This compromise, though it is not a new invention, seems to offer a practical solution of the difficulty, and we may expcet that the system of using cartridges with a large rim will gradually fall into disuse.

Propellant.- We need not linger over the explosive. Cordite has survived much criticism, and justified itself as a stable, efficient, and very controllable propellant, trustworthy in all climates of the British Empire: Its chief drawback, excessive erosion, may be diminished if the modified cordite, containing only $30 \mathrm{per}$ cent. of nitro-glycerine instead of 58 per cent., can be made available for the rifle as it has already been for larger ordnauce.

\section{VELOCITY.}

We may here pass for a moment to the subject of velocity. The advantages of imparting a high velocity to the rifle bullet need hardly be insisted upon. It has been said, and not untruly, that the ideal bullet should travel for 3,000 yards in a straight line and then drop to the ground. The nearer we can approach to this impossible ideal, the more efficient will our weapon be. Penetration and force of blow are of course important. Formerly a tree of ordinary thickness gave 
good shelter against rifle bullets; now it would afford no sufficient protection.

But it is not penetration that is the chief justification of high velocity. The one abiding difficulty of the effective use of projectiles in war is that of adjusting the aim to the distance of the mark. So long as range finding remains what it is now, little more than a matter of guesswork, the importance of a flat trajectory will remain enormous, for it diminishes the necessity of accurate guessing.

The German Army in 1870 used the needle gun, giving-a velocity of only 1,000 feet per second. In 1880 the highest velocity of military bullets was 1,500 fcet, while of modern rifles none give velocitics materially below 2, 000 f.s., and some - those of Holland, Italy, Roumania, and Japan-attain or approach to 2,400 f.s. What, then; is the actual benefit to be obtained by such an increase of velocity?

Let us take the "dangerous zone" for an object 3 feet ligh at 1,000 yards. At this distance:-

With the Enfield or Snider the bullet took $11 \frac{1}{2}$ yards to fall 3 feet.

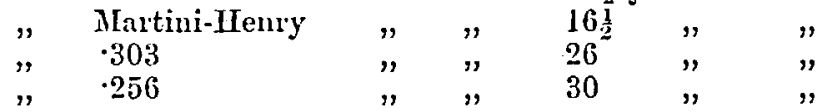

In other words, to hit a knceling figure 3 feet high at 1,000 yards, the distance must be judged :-

With the Enfield to within 6 yards one way or the other.

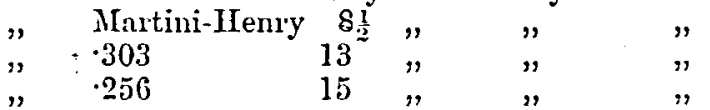

The difference here between the 303 and the $\cdot 256$ does not sound very much, but it is an addition of 15 per cent., and therefore very material. Similarly the rise and fall of the 303 bullet does not exceed 3 fect for the frrst 460 yards, or so, of its flight; but that of the $\cdot 256$ is within the same limit for about 25 yards further-a very material extension. We may consider that the Japanese rifle has rather more than this advantage over the Russian rifle. So far as can be judged from measurement of the sights of the new U.S. short rifle, the trajectory is slightly flatter than that of the 256 . The American bullet is rather more pointed, but its capacity for flight is very similar to that of the '256. It is cvident that, subject always to the necessary limitations, it is worth while to carry velocity as far as is practicable. It gives materially increased penetration-a matter of importance in some circumstances. The penetrative intensity of the 256 bullet is at all ranges about 25 per cent. greater than that of the $\cdot 303$. It therefore has in this respect a naterial advantage. On the other liand, it is rather more susceptible to the lateral influence of wind, but probably not enough so to be at any material disadvantage. The smaller diameter of the bullet may for practical purposes be taken not to affect the wounding power. High velocity is not inimical to accuracy, but rather favourable to it.

An increase of velocity in a rifle entails the passage through the bore of a larger flow of gases, presumably under an increased pressure. This means increased erosion of the barrel as well as increased wear from the bullet. A still more important factor limiting the increase of 
velocity is the pressure. In adding to the charge in a cartridge, pressures are necessarily increased, and this can only be avoided by an increase in the capacity of the cartridge, to give a reduced gravimetric density. Such an enlargemeut of the cartridge has been made in the U.S.A. rifle, and in that case it is combined with an increase in pressure.

The Barrel.-There are other factors affecting velocity which are connected with the barrel.

1. The length of the barrel has an important bearing on the velocity, and, as already mentioned, it has tended to become shorter in the last five decades.

In the case of British Service rifles, the length has been reduced as under:-

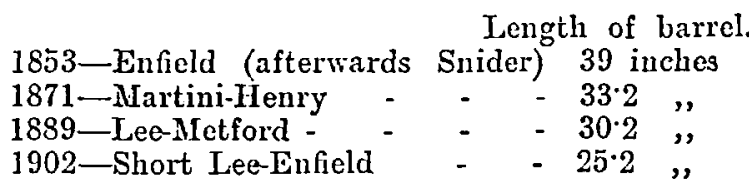

In the corresponding period the barrels of the German rifles have been shortened from 35.4 to $29 \cdot 05$ inclues.

The older rifles were necessarily longer for bayonet work than the new. But a comparatively long barrel was also necessary for firing in 2 or more ranks in close order. The short rifle may be taken to mark the abandonment of close-order firing in more than one rank.

The additional velocity given by a longer barrel as against a shorter one is fully worth consideration. The trials of the experimental short rifle of the U.S.A. gave a reduction of 87 f.s. for the reduction of 6 inches in length ( 30 inches to 24 inches), and the charge was consequently added to so as to increase the velocity of the short barrel by that amount, from 2,173 f.s. to 2,260 f.s. at 53 feet from muzzle.

It is one of the advantages of modern propellants that a high velocity can be imparted by them in a barrel of short length in a way which was impossible with black powder.

2. The velocity is also affected by the amount of friction and leakage of gas as the bullet passes from the cartridge into the barrel. Here construction of the "lead" or cone connecting the chamber with the rifling is an important element, and its shortening in the L.-E. short rifle is entirely to the good.

3. A third factor is the degree of friction in the bore and grooving, due to the construction of the barrel. The deepening of the grooves towards the muzzle in the short rifle appears to be quite a new departure. It is not clear what is the degree of increased velocity attributable to this cause. The increased depth of grooving brings some danger of an escape of gas past the bullet, which is undesirable.

Calibre.-The reduction of calibre which took place generally in military arms about 20 years ago was a startling development, received at first with hesitation, but made a success by the invention of practicable smokeless explosives. It was only by the reduction of the calibre that it was possible to achieve the reduction in the size and weight of the ammunition necessary to make the box magazine available as an addition to the rifle, and to enable the soldier to carry a much increased number of rounds. The whole cartridge of a modern military rifle is over 50 per cent. lighter than the M.-H, cart- 
ridge, and does not weigh so much as the bullet fired by that rifle. The bulk of foreign Powers have, like ourselves, adopted calibres of $7 \frac{1}{2}$ to $8 \mathrm{~mm}$., or about $\cdot 300$ to $315 \mathrm{inch}$.

The opinion of nations is at the present time divided as to the advantage of a further reduction of calibre. Italy 14 years ago adopted the $61-\mathrm{mm}$. (256) rifle of Mannlicher type, and this lead has been followed by Roumania (1893), Holland (1895), and by that very practical people the Japanese in 1900 . Meanwhile Spain has an intermediate calibre, the 276 (7-mm.) Mauser, familiar to many here as similar to the arm of the Boers. The U.S.A. lhaving in 1898 boldly adopted the very small calibre of $\cdot 236(6-\mathrm{mm}$.) for the arm of their $\mathrm{Navy}$, shortly afterwards abandoned it, and have now altered the form of their cartridge, so as to get a higher velocity, but have retained their calibre of $\cdot 300$. Germany modified the pattcrn of her Mauser rifle in 1898, but did not change the cartridge, and Switzerland did the same in 1900. Mexico is said to have adopted the Mondragon rifle of $5-\mathrm{mm}$. ( $196-i n c h)$, and with a rifle of similar calibre produced experimentally in Switzerland by Colonel Rubin, he lias obtained high velocities; but so small a calibre does not at present appear to be practical. For if the pressures are to be kept within reasonable limits, the cart ridge must be enlarged to an awkward shape, while the barrel necessarily suffers more from the action of the gases and of the bullet upon it. Undue reduction of the calibre involves a loss of wounding power at very long ranges, and increases deflection of the bullet by the wind.

There is much more to be said for the calibre of $61-\mathrm{mm}$. $(\cdot 256)$. It gives a velocity of $2,400 \mathrm{f}$.s. without immoderate pressures. To compare it with the rifles of 300 to 315 calibre, it may be said that its bullet is as well proportioned (if not better) for flight, and that it is not deficient in wounding power. The present war should give more information on this point. It certainly makes an admirable weapon for soft-slinned game. Though its blow is less at extreme ranges, its higher velocity gives it an advantage in penetration and in flatness of trajectory-very important matters. On the other hand, the projectile is somewhat more affected by wind. The ammunition has, however, one definite advantage. The cartridge weighs from 330 to 350 grains, or 15 per cent. Jess than our cartridge. It weighs 22 per cent. less than the new U.S. cartridge of 300 bore, which gives the same velocity; and it is decidedly less bulky. It is interesting that this smaller calibre should now be undergoing the test of war. The chief doubtful point about it is the increased wear and erosion in so small a calibre. On this, Japanese experience should now be able to throw some light. Cordite as now used in our rifles is perliaps too erosive a propellant for a $\cdot 256$ rifle; but the Italians use ballistite, which is of much the same character.

\section{Accuracr.}

This is the quality which distinguishes rifles as a class from their smooth-bore predecessors, and a well-designed modern military rifle almost as much from the earlier rifles. Accuracy is a very necessary quality if the fighting man is to have confidence in his arm. Manufacture at the present time is so exact, and the limits of variation between individual rifles made in quantity are so narrow, that accuracy 
or inaccuracy is far more a question of design than of make. It should not be necessary to labour the point that rifles should shoot as accurately as is possible within reasonable manufacturing limits. It is true that the bulk of firing in war must always be of the rough and ready kind. It is true, too, that only some men are capable of taking full advantage of the accuracy of the weapon; but these should not be unduly handicapped, for there are many occasions in war when accurate marksmanship goes for much. Nor can the necessary interest in getting the best work out of his weapon be aroused in the recruit, or maintained in the trained man, unless it is capable of responding to every demand that he may make upon it.

Barrel.-What are the chief causes of inaccuracy in rifles? As regards the design of the barrel, they should be few. There is a strong family likeness in the grooving and the spiral of modern rifles. It may be questioned whether the complications in manufacture introduced by tapering the depth of rifling, one way or the other, as was done formerly in the Martini-Henry, and recently in the L.-E. short rifle, are balanced by a sufficient real advantage. The same remark applies to the increasing spiral or "gaining twist" which Italy alone of nations has thought it worth while to introduce into her Service rifle. The design of the barrel at the "lead" (already referred to) is also of importance as regards accuracy.

Bullet.-Any variation of friction in the barrel, as the bullet passes along it, tends to inaccuracy; consequently, the condition of the surface of the bore is of importance. The heavy pressure of metal upon metal, as the bullet is "swagged" into and through the bore, is apt to leave on the bore what is known as "metallic fouling." This deposit tends to rust as well as to inaccurate shooting. The material of the bullet envelope is therefore important. Opinion is, on the whole, divided between cupro-nickel (used for our Service bullet) and steel coated with cupro-nickel, to prevent rusting. The latter makes less metallic fouling, but perhaps wears the grooving more. Japan uses a copper-clad bullet, and Switzorland one of hardened lead, with a wrapping of paper to keep it from contact with the bore, the tip being sleathed with a thimble of steel, coatod with cupro-nickel. Such a compound builet cannot but make a much more smashing wound than the ordinary pattern of sheathed bullet. There is room for improvement in bullets in the direction of reducing the friction which takes place in the bore. $A$ bullet without a cannelure gives somewhat more accuracy and decidedly greater penetration than one having a cannelure, as lias been proved in recent experiments in this country and in America.

Pressurcs.-One of the factors in accuracy certainly is, that the pressure set up by the ignition of the charge should not be too low. It would seem that a low pressure allows an undue rush of gas round the bullet before it is fairly in the rifling. In this respect, there is scme advantage in the nse of a higher pressure than has been the rule with our Service ammunition. The pressure at the muzzle, on the contrary, should be low rather than hich, for the most critical point in the course of a bullet is that at which it clears the bore and unseals the gases, which rush round it and tend to unsteady it. This increased muzzle pressure is one of the factors to be considered in designing a rifle with a shortened barrel. 
The 303 rifle, with a well-made barrel and a properly designed bullet, is capable of making quite as accurate shooting as the best of the Continental rifles. With ordinary Service ammunition, however, it is slightly inferior to the -256 Mannlicher (Dutch pattern) and the $\cdot 276$ Mauser (Mexican pattern). It would almost seem as if the L.-E. short rifle as produced in the ordinary run of manufacture is not up to the standard reached by it when in the experimental stage.

Sights.-Upon these depends the degree of accuracy which can be obtained from a rifle when the human element is introduced. Shooting from the fixed rest merely tests the accuracy of the barrel, and not that of the weapon in the soldier's hands.

The foresight in foreign rifles is almost univcrsally of the barley-corn or coned slape familiar to us. It is the strongest form, but has the disadvantage that whether more or less of the sight is seen over the backsiglit, the proportions of it remain the same. In the United States rifie, the foresight is a thick blade with parallel sides. A strong foresight of bead shape (the form which is generally preferied for sporting purposes) was tried experimentally for the L.-E. short rifle, but the barley-corn was preferred. The addition of a handguard to the rifle necessitates the raising of the sights, so that the line of aim may not be interfered with. But in military rifles, such as the Lee-Enfeld, which have an upward throw or jump, the foresight necessarily stands on something of a high block, in contrast to the very low block necessary in the Snider and Martini-Henry. Owing to the distortion of the barrel inseparable from brazing, and to the liability of solder to melt when the barrel is heated by firing, it is now usual to form the foresight and backsight blocks with rings beneath them, fitting the barrel, and pinned to it. In the L.-E. short rifle, the foresight is so made. The backsight has a curved bed fitting the barrel, and is fixed by screws.

In the same rifle a new departure has been taken in having a very complete and strong protection for the foresight permanently fixed to the rifle. Two strong side-pieces, made as part of the nosecap, rise on each side of the sight, and curve inwards above it. They are roughened so as not to catch the light, and effectually guard against damage from a fall or a blow.

Backsights are of two types. The first is that to which we have hitherto bcen accustomed on our military rifles, in which elevation for the first 400 or 500 yards is given by moving a slide along a ramp, and elevation for longer ranges by raising the flap to a vertical position, and adjusting the slide upon it. This type of backsight is used by a majority of nations. In most examples the slide is locked by means of a catch fitting into notches cut at intervals, as at each hundred paces or metres, and the sight cannot be adjusted for intermediate ranges. The backsights of the Belgian, French, and Russian rifles, as of our own Lee-Enfield and its predecessors, clepend on springs for holding the slide in position; it can therefore be adjusted accurately wherever necessary. The slide on the Lee-Enficld backsight has the grave disadvantage that it is liable to become loose by wear, and to shake down with the shock of the discharge. If it fits tightly, it is difficult to adjust, especially with cold fingers.

The backsight approved for the new rifle is of the second type; that in which the sight is hinged, and in which its rising motion is 
continuous until it is nearly upright, the same $\mathrm{V}$ being used at all distances. A spring catch engaging in notches holds the sight firm, at fixed intervals of yards or metres. To obtain an adjustment for intermediate distances, the L.-E. short rifle has the V carried on a small slide, moved by a vertical screw. A similar slide moved by a transverse screw enables allowance to be made for wind. The British rifle is the only military rifle having this refinement. A new arrangement was adopted some time since by the United States for the Krag-Jorgensen rifle, in which the backsight was pivoted and could be turned laterally through a small arc, and clamped in the desired position. This form of sight appears to have been abandoned in the United States short rifle, the backsight of which has no lateral motion.

Opinions differ as to the value of a lateral adjustment, but it may be said that, though it camnot be used for rough and ready work, it is of great advantage in any circumstances, whether in peace or war, in which really accurate shooting is desired. It has especially an advantage in the instruction of recruits, by enabling them to aim at their mark, even in a side wind. It is most discouraging to the learner to be expected to aim right away from his mark, perhaps even so far that he has to lose sight of it entirely, and it is not more difficult to teach the beginner to adjust his sights laterally for wind than vertically for elevation.

In aiming at extreme ranges, over the ordinary backsight, the neck has to be craned, or the butt brought very low on the shoulder. There is thus an advantage in laving the line of aim Iowered for the farthest distance. In the British, the Dauish, and the older pattern of Austrian rifle, this is provided for by a.method of sighting alcngside the fore end and not over the barrel. Our own aperture backsight and dial-sight have proved themselves useful. The aperture sight has great advantages, as sportsmen know. The radius (or distance between foresight and backsight) of the long-range sights is only about 16 inches. The radius of ordinary sights is governed first by the length of the barrel (the foresight bcing placed as near the muzzle as is practicable), and secondly by the necessity for kecping the backsight far enough from the eye to obviate undue blur in aiming. The sight radius of the Lee-Enfield rifle is $21 \frac{1}{2}$ inches (flap down) and 23: inches (flap up). That of the L.-E. short rifle is 19 inches. The U.S.A. short rifle, with a barrel 1 inch shorter than that of our short rifle, has a sight radius of 23 inches, 4 inches more. This is obtained by bringing the backsight as far to the rear as possible; instead of being 24 inches in front of the heel of the butt, it is only 191 inches from it. No nation las attempted to introduce telo scopic sights upon rifles, useful as they would be in skilled hands on some occasions. It has been suggested by Lieut.-Colonel Mayne and others that rifles fitted with them might well be issued to certain picked marksmen in each company. But, so far, the practical difficulties have proved great. Their cost would be considerable, and they cannot but be liable to be damaged, or put out of adjustment. They have proved useful enough both in the backwoods and on the deer forest. But it is quite another matter to adai them for adjustment in a large arc of eleration. 
The following are the extreme distances to which the rifles of various countries are sighted, expressed in yards :-

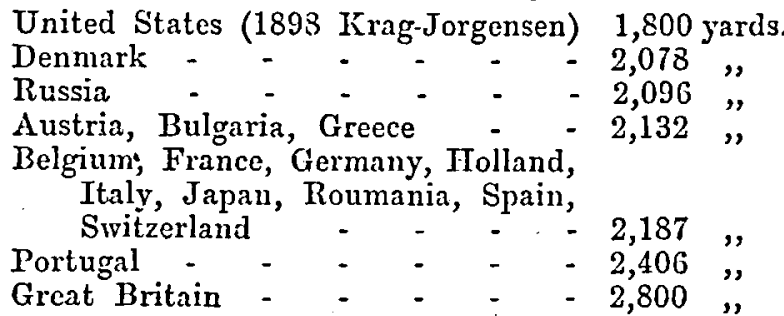

In the Boer War, as is well known, our rifle was on occasion fired at distances up to its extreme limit of sighting.

The adjustment of the sighting of every rifle made is a very necessary improvement recently introduced into our factorics of military arms.

\section{STock.}

The French rifle and our own are the only two which have the stock completely divided by the action. The divided stock was introduced in the Lee-Metford partly in order not to waste the material for butts and fore-ends which had been at the time provided for the MartiniHenry. The stock bolt, securing the butt to the action, undoubtedly strengthens the stock at its weakest part-the small. On the other hand, there is a tendency for the bolt to become unscrewed under the strains it meets with, and under shrinkage of the wood. If this happen, as it may on active service, the butt becomes loose. The divided stock undoubtedly adds slightly to the weight of the arm; but in case of breakage, either part can be replaced separately.

The barrel groove in the fore-end of the L.-E. short rifle is enlarged so as only to touch the barrel at the reinforce, at the lower band, and near the muzzle. This much reduces the probability of the barrel having its shooting affected by the warping of the fore-end. A somewhat similar provision is made in the case of the Swiss rifle.

In the Iee-Enfield rifle the pull-through and oil bottle were carried in the butt, in the hole made for the stock bolt; this has been discontinued in the short rifle. Weight is thereby saved. The practice of carrying these cleaning materials in the stock has not commended itself to other nations.

In.the short rifle the butts are made of 3 different lengths, to suit men of short and long arms. This is a reversion to a practice which prevailed with the Martini-Henry, the stock of which was made in 2 different lengths, and is based on a sound principle. Though a man may get used to a stock of almost any length, it is a great help in suapshooting and quick work if the stock bears some kind of relation to the proportions of the individual. This is fully recognised by all sportsmen.

IIandguard. - The Belgian Nauser and Danișh Krag-Jorgensen have the barrel protected by a steel tube or casing, touching it only at the breech and muzzle. On this casing the sights are fixed. The German rifle (pattc 'n 1888) had a similar casing, but it was abandoned in the 1898 pattern Such a casing acts as a substitute for the handguard, and as a protuction to the barrel. But to save weight the barrel has to be made thinner, and therefore weaker, while the casing 
itself has hardly sufficient substance. It adds to the cost both of manufacture and repair, and rust is apt to be set up within it.

With magazine fire an ample handguard is necessary. The great heat developed by rapid fire makes it impossible to touch the barrel with the naked hand after a few shots. And it must be possible for bayonet fighting to catch hold of any part of the rifle. It is right thcrefore to sheath the barrel in wood for all, or nearly all, its length. Another advantage is gained by so doing. The heated air rising from the naked barrel when hot is apt to blur the vision in looking along the sights, and the wood casing avoids this drawback. The new U.S.A. short rifle, like our own, has its barrel completely cased; other nations content themselves with a handguard extending to the lower band.

\section{The BAYONET.}

With regard to the bayonet, the conditions have changed more than is commonly realised. It was, in the first place, a substitute for the pike. Cavalry could rifle down any infantry not protected by a high and continuous spiked fence. Viewed in this light, the length of musket (or rifle) and bayonet must of necessity be sufficient to keep the mounted man and bis horse at a safe distance.

The hammerless breechloador did much to enable the foot soldier to substitute bullet for bayonet in many circumstances. The magazine rifle has done much more, and that is why we find that a reduction of 10 inches in the length of the bayonet weapon was possible when the Martini-Henry was superseded by the -303 rifle. This great roduction, from 5 feet $11 \frac{1}{2}$ inches to 5 feet $1 \frac{1}{2}$ inches, was found to be rather an advantage than otherwise in quick fencing work. The main use of the bayonet, in fact, is no longer as a defence against cavalry; it is for the final charge and hand-to-hand tussle, and for exceptional occasions at close quarters. The long reed-shaped bayonet of the Martini-Henry was ill proportioned; it was too long for its weight. The knife bayonet has the advantage of being available for many purposes in campaigning. Whether or not we can afford some further reduction in the length of the bayonet-weapon, if it can be made handier and quicker in use, is a question of fact, and one not difficult to decide by trial. Armies no longer come to "push of pike," and length is not everything in a weapon which exists mainly for use in a scrimmage. With the musket and rifle of large bore, the bayonet was fixed to the barrel, which was stiff enough to carry it with a small amount of support from the fore end. In modern rifles, the reduceil diameter of the barrel makes a zreater stiffening necessary. The attachment of the bayonet to the barrel affects (as is well known) the direction of the bullet, and in the new British rifle it has been thought well to attach the bayonet to the fore end and not to the barrel. This demands a heavier nosecap ( $7 \mathrm{oz}$.$) , but it saves the barrel from the$ risk of strain. The bayonet of the German Nauser is similarly attached to the fore end and not to the barrel.

We sometimes see an ancient blunderbuss fitted with a short bayonet, which lies under the stock, and on a catch being released springs round into the proper position for use. This has the advantage that the bayonet is inseparable from the weapon. The carbine with which the Italian troops are armed has a bayonet of triangular section, hinged to the nosecap and folding back when not ir, use, so 
ast to lie under the fore-end. The carbine and bayonet weigh just under 7 lbs. Its length, with bayonet extruded, is 40 inches, and it is considered to form an effective thrusting weapon for the cavalry soldier to use on horseback.

The United States have endeavoured to make use of a permanently attached bayonet in their new short rifle. A pointed rod lies under the barrel in the stock, being held by a catch. The catch being released, it can be pulled forward, and the catch again holds it. In this position it gives a bayonet weapon 4 feet 6 inches long. The rod can be detached altogether from the rifle, and is of diameter small enough to be used as a clearing rod. It is understood that this form of bayonet $e^{2}$ is not likely to be retained. Its limitation in size to the internal diameter of the bore entails a great want of strength. There is of course some advantage in the bayonet being inseparable from the weapon, but if it is to be strong enough for its purpose its eight is better carried on the waist-belt than ailded to that of the rifle. So carriod it is available as a hand weapon when the soldier is otherwise unarmed. The knife bayonet has amply justified its existence.

There has constantly been a tendency to sacrifice strength to length in bayonets. Under excessive strain, however, even a well proportioned steel weapon must either bend or break. $\Lambda$ blacle that snaps is for ever useless. Good as is the cutlery of the Japanese, they have had many bayoncts bent in the present war. The length, including the fixed bayonet, of the rifles adopted by different nations before 1880 was from 5 feet 11 inches to 6 feet 2 inches. Those of the present day measure as follows:-

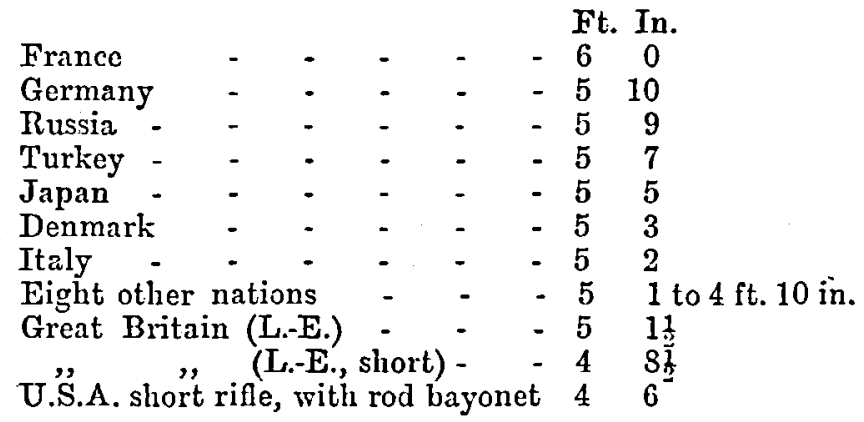

\section{Future Progress.}

What then, are the indications of the lines which future progress in - tary rifles will take? To take first rapidity of loading. The automatic rifle will probably come some day, a rifle requiring only the pulling of the trigger to discharge each fresh shot. But it has disadvantages, hoth in complication and in weight. To exceptionally cold climates it would be ill-suited. Did we not read of Maxim guns which failed to work in the fighting in Tibet? Such difficulties have even interfered with the working of the ordinary bolt action; with more elaborate mechanism they may become serious. As regards rapidity of fire, it is well known that where the recoil is enough to shift the alignment of the barrel, the time necessary to recover the aim much limits the possible rapidity. The two automatic rifles tried at Bisley last July did not give a rate of fire so hijh 
as has been attained by experts using the hand-operated magazine rifle. This was mainly because the recharging of the magazine could not be done with proper expedition. An automatic shot gun carrying 5 cartridges in a tube underneath the barrel has been put on the market, and is a useful weapon.

If an automatic rifle of sufficiently simple design can be produced, it is likely to be adopted at all events for certain purposes, as for defensive positions where there is no difficulty as to ammunition supply. And the moral effect of an automatic rifle is such, that if one great nation should adopt it, others are bound to follow suit.

On the other hand, it may be some time before any nation takes the plunge. Assuming a practical automatic rifle for infantry to be produced, the cost of re-arming with such a rifle would be very heavy. Mechanism is always expensive, yet in matters of national armament expense never stands long in the way of progress. Another difficulty is in the ammunition supply, a difficulty great enough even now in the case of a force moving rapidly away from its base. It would be much increased were the expenditure of ammunition in battle to be much added to. Automatic loading mechanism must certainly involve increased weight and a diminution of handiness.

We may conclude then, that the times are hardly ripe for the adoption of an automatic rifle. Meanwhile, the best opinion decidedly leans towards a rifle giving a velocity of 2,300 to $2,400 \mathrm{f} . \mathrm{s}$., and we may, perliaps, see even higher velocities than this in use before long. To obtain such high velocities, the calibre is not likely materially to exceed 256 ; for the weight and bulk of the ammunition impose a limitation on the bore. The action will have ample resisting power in lugs placed at the head of the bolt. The cartridge will be practically rimless. The weight is not likely to be reduced much below $8 \frac{1}{2}$ lbs.

The progress of military rifles has been very rapid in the last 25 years. To project a bullet weighing less than $\frac{1}{2}$ oz. to a distance of 2 miles with great accuracy, and with such velocity that it will penetrate a foot of timber at 1,000 yards, was beyond the dreams of our ancestors. In rapidity and certainty of fire, and in simplicity of equipment, the modern soldier enjoys advantages which 50 years ago were hardly conceivable. As further openings for improvement arise, it will tax all our wisdom as a nation to take advantage of them at the right moment. To make no hasty change, yet never to be left behind in the march of improvement, is always a hard problem, and one even harder for a nation than for an individual. We cannot afford to neglect any of the lessons of experience, whether those of the South African war, or those of the conflict, much more typical of the fighting of moderu land-Powers, nov being waged in Manchuria.

IIave we been right in remodelling the 303 so completely? Would it have been wiser to add to it only the simplest possible mechanism for quick loading, as a temporary measure, and to have cmbarked at once on a rifle more up-to-date in certain respects at a much increased cost? Will the present converted rifle last us satisfactorily till yet greater changes begin to press? Such questions as these are not easily answered with certainty, since they imply a correct judgment of the future, yet upon a right answer to them much may depend. 
Licut.-Colonel C. B. Marke, R.E.:-I have admired as much as anybody the moderation of the views of the lecturer upon the very vexed question that has been so much before the publie of late. I eannot say that I know anything practically about the new rifle, so that I am not going to speak either for or against it. I have fired two bullets from it at a 30 -yard range, and that is my only practical accuaintance with it; but $I$ do protest most strongly against the arguments that have been used lately in the Press for the purpose of running it down. These arguments, which appear pretty frequently in different forms, have absolutely nothing to do with the battle-field. I have wondered whether the gentlemen who carried out certain experiments that have been alluded to in the Pross have ever seen any active service, or, if they have, whether they cmembered what takes place in action. The whole opposition to the new rifle scems to me to be based on the sole idea of pot-hunting over measured ranges, under conditions which are not in any way suitable to war. My protest is not against the new rifle, but against tho arguments that have been used against it. The only way to test any new rifle as to its fitness for our Army is to test it on a large scale, with a large number of troops, under various conditions of field firing, and under conditions which approach those of war as nearly as it is possible to do so, and then to sce what the results are, as compared with other rifles tested in the same way. Until that is done, I should waive my judgment on any rifle that is put forward, however theoretically perfect it may be, for reasons that you will see in a few moments. I may also say that only last week a gentleman, who has shot a good deal at Bisley, was complaining very bitterly to me that he had lately paid $\$ 9$ for a barrel, and that he could only sell it for 22 , because he was unable to certify that 300 shots had not been fired from it. In the present war, what is going on? Statistics have come home to us showing that the normal amount of ammunition that has been fired is about 400 rounds per day per man. Since that is the case, and if the rifle is perfectly true at the beginning of the day, what must bo its condition at the end of the day, when 300 rounds make a difference in an accurate target-shooting rifle? At the end of the day it is practically not worth being considered as a good shooting weapon; and at the end of the second or third day you may inagine its condition. Some of the battles which have taken place in Manchuria have lasted ten and twelre days, and even longer, and $I$ would like to see some of these rifles at the end of the tenth or twelfth day. As probably the barrels have never been cleaned out, the chemical action of the products of combustion must have eaten into the surface of the bore, while the metal-coated bullets have probably worn away the grooving of the barrels. 1 Where does your accurate shooting come in under those conditions? My own riew of this matter is (and I daresay some

IA gentleman who was present at the lecture, and who had just returned from Manchuria, after seeing much of the fighting there,-told me afterwards that what I had surmised about the condition of the rifles on both sides; Russian and Japanese, was perfectly true. But he added that my statement that the Japanese bullets mushrooned was not correct. The bullets used in the war had but little stopping power if they did not hit a vital spot, and the majority of wounds they made wero not serious. He considered that artillery fire was the commanding factor on the battle-field,-C. B. M.

For. XIIx. 
of you know I have studicd the question for a great many years) that wo should try and consider the conditions of the battle first, and then produce the rifle best fitted for that purpose. First of all there is the tactical effect. Major Fremantle has told you how the rifle ras used for very long ranges in South Africa. Was it worth it? From all accounts $I$ have heard of what took place in South Africa, no long-range firing was ever worth the expenditure of ammunition. In no instance in the fighting out there can I find a case in which our troops had any difficulty in getting to within 800 yards of the Boers; in fact, at Maggersfontein our troops lay from two to three hundred yards in front of the Boer lines all day long, and the losses only began when the retirement took place. Besides, the long-range power of the rifle is simply the effect of our efforts to get a low trajectory. Wo have heard a good deal about the high relocity, but it must bo combined with the sectional density of the bullet. You can have a high velocity at very short ranges, but which will fall off very quickly, as in the case of the old spherieal bullet. Fou must combine high velocity with high sectional density, and that is the reason for long ${ }^{1}$ bullets of small diameter, in order to get a low trajectory for is long a distanco as possible. Then comes the question of rounding power. I mere perforation is nothing. We know that in many of our wars, men have been perforated again and again with small bullets, and in the Tirah campaign re had Afghans coming in with five, six, or seren bullet rounds for treatment. High velocity must be combined with some stopping power. There was an outcrs against the Dum-Dum ammunition, which made the bullet mushroom a bit; but $m y$ omn impression is, from all $I$ can hear, that the Japanese bullet and the French bullet do mushroom, and yet nothing is said about it. However, we gnve way about it. As regards tactical effect, the ranges in battle are all fairly short, as we see in the present war. We often read of the combatants coming to close quarters with the bayonet; and we also read that they are throwing hand grenades. That has happened, in my opinion, for two or three reasons. One is that the eating arras and wearing out of the barrels has made the rifles of both combatants perfectly worthless as regards accurate shooting; and in the next placo-and this bears rery materially on the question of the automatic rifle-when men have to lift and lower their rifles something between 300 and 400 times every day, they are physically done up; their firo is probably absolutely worthless so far as accurate shooting is concerned after raising the rifle 50 or 60 times. And for these reasons they are able to approach each other with comparative safety. That sort of thing going on day after day, with heavy marching and broken rest, and the men physically done up, accounts for tho short ranges within which, eren with improred weapons, combatants aro nowadass able to get near each other. Then again, the power of vision of the greater proportion of our men, particularly in a country where we recruit so much from the towns, is governed by the length of the street in which they lire. When they go out into the country they cannot see clearly rery far, and it takes time to train their vision to enable them either lo see rell to any distance or to clearly distinguish objects at given ranges. Wo found that very strikingly exemplified in South Africa, where the Bocrs were stated to be able to sce clearly tro miles further than our men could. Then again, there is the invisibility of the enens, which completely militates against our getting accuracy of fire at any range. Then

"That is, "long" as measured by" number of diancters in length.C. B. $\mathrm{M}$. 
comes the question of the adjustment of the sighting to the ranges, which is a very important matter. The lecturer has very rightly laid stress on the great need of a flat trajectory (i.e., under the height of a man) for as long a range as possible, in order to reduce as much as possible the need for altering the sights by men excited by danger. The proportion of error in guessing ranges is so rery great-probably one-sixth for the longer-ranges to one-eighth for the shorter ones-that the theoretical percentages given by the lecturer are of very littlo value. Then comes the question of the expenditure of ammunition. As I hare said, it is rery great, and the mere lifting of the rifle up and down some 300 or 400 times a day must have a great effect on the men. Added to that, there are the questions of the energy of recoil, the making use of corer, and snap-shooting. All these items weigh a good deal in considering the question of the length of the barrel. Morcover; the convenience of movement on the battle-field has not been considered in any of the discussions on the new rifle. Those who have been in India know that the Government of India allows officers to get rifles from the ordnance factories, which rifles remain their property while they are in India. When we used to get the old Martini-Henry it was converted into a splenclid sporting weapon by cutting off the fore-end from about an inch above the lower band. That improved the shooting most ronderfully. Perhaps our lecturer will consider that point, as I feel pretty well certain the real reason of the inferior shooting of that rifle, with the fore-end and upper band left on, was because the upper band squeezed the barrel, and as there must be a ware of metal as the bullet swags up the barrel, the bullet is checked by the band near the muzzle. It is probable that that check has been reliered in the new rifle, partly by the deepening of the groores near the muzzle, and partly by the new method of attachment to the fore-end, which may account for the better shooting and the increased velocity that has been obtained by their introduction. Morcover, for all our small game shooting out there everybody went in for the short Ice-Fnficld cavalry carbine, which was a very favourite weapon for deer shooting in the jungles, because it was so convenient to get about with it under corer and over rough ground. Fren leopards have been shot with it. It is lighter than the rifle, and therefore lightens the load to be carried, on which so much stress has been laid. It was said that the rifle ought to be lightened in order that the men can carry more ammunition. That I do not think is needed. On the line of march you need not carry more than 50 or 60 rounds, and when an action is imminent, the remainder required for it can be issued. If a good rifle can be obtained by increasing the weight, the ammunition question can be lealt with in other ways. I have spoken of the rounding power of the bullet. The $\cdot 256$, if sou can get it to set up in any ray, would have sufficient wounding power. We know that the present 303 , which does not set up. has not sufficient wounding. power, and will hardly stop horses. One of the dangers to infantry of a caralry charge in modern fighting is the inadequacy of the modern bullet to stop caralry, unless it can be made to set up. With regard to the question of accuracy, the accuracy of modem rifles is far greater than the vast majority of men can make use of. All those who have been in action know that the men cannot make use of the accuracy of the rifle which is put in their hands, owing to the limitation of their power of vision, their fatigue, and the excitement of battle. I would like to ask those gentlemen who have been in action how often they found their men change their sights, when once within 800 yards from the enemy. The accuracy of the rifle depenris on the sighting; and 
in the great excitement the men will not change their sights. What constitutes the great value of a low trajectory is the fact that the men need not bother about the sights after a certain period. All firing in battlo can only bo a fire of probability, that is, endeavouring rather to cover certain areas of occupied ground with bullets, expecting a certain percentage to hit, rather than any idea of accurate marksmanship, which is a condition wo never can reach. It is futile to ever try and reach it, and we should take up the more sensible position of corering occupied areas of ground with bullets, especially where we can see where the bullets are falling, and hope that some fair proportion of them may hit the enemy". With regard to the question of the distance apart of the sights, of which so much has been made, it would make a good deal of difference to a good Bisley shot as to how far the sights were apart, but to ninety-nine out of a hundred in the Service a few inches one way or the other make no difference at all. I know it makes no difference to me; but I do not claim to be a good shot; in fact, I shoot just as well with a short as with a long barrel, simply because I am unable to make use of the extra accuracy given by the longer distance between the sights, and ninety-nino soldiers out of a hundred, or perhaps more; are just the same. $\Lambda \mathrm{s} \mathrm{a}$ matter of fact, the whole of this question really turns upon trying the new rifle against the old rifle with a large number of men at field firing, not for one day only, but for several days, and then to see what the results are. That is the only test which will be of any practical value. Something should be said about the thickness of the metal of the barrel, which must liare a very great effect on the accuracy of the rifle, and the wavo of metal that nust go up in front of the bullet, and which is checked by any band fastened around the barrel. Therefore, it is of great in. portance, for sereral reasons, to have the bayonet on the fore-end, and not on the barrel. You will see in the new rifle that the bayonet has nothing like the same effect in altering the trajectory for any given sighting as it had in the long Lee-Enfield, because it is now fixed to the fore-end and not to the barrel. If it is fixed to the barrel it affects the vibration very seriously, and therefore alters the throw of the bullat altogether. it does not do that anything like to the same extent in the present rifle. In conclusion, I would like to say one word about the automatic-loading rifle, which is the one thing the lecturer has thrown cold water upon. I think by a slip in writing he las mixed up the question of the rapidity of loading with that of the rapidity of firing. Rapidity of firing, I admit, is almost absolutely useless. Men can fire away any amount of ammunition in a very short time and hit nothing; but rapidity of loading is a most valuable factor in a military rifle: to always have a cartridgo ready in case of need. I hare spoken of the constant raising and lowering of the rifle. With the automatic rifle you only have to raise and lower it one-tenth the number of times, supposing you hare 10 bullets in the magazine, as compared with the ordinary rifie. Moreover, since you do not have to bring the rifle down after every shot, you stand a far greater chance of hitting an advancing target, as you do not have to take your eje off it. We know that the Boers charged through our lines in the South African War, and we also charged through their lines; in these cases the rifle had to be brought down quickly, loaded, and brought up again, and under those circumstances, combined with hurried aiming and excitement, you cannot get accurate shooting. With the rifle up you can follow your man, and I beliere the majority of men would drop a charging enemy long before he got up to them if they did not have to bring their rifles domn erery time, which is a very strong reason for 
using the automatic rifle. It reduces tho recoil, it reduces the fatigue of lifting the rifle, and you get much better shooting results, especially, as I have said, at charging cavalry. The question of the expenditure of ammunition has been referred to; but that argument has almays been used when any new riflo has been introdneed. Lord Roberts and others gave evidence before the War Commission that our soldiers in a very short time learned to value their ammunition, and would not throw it awray after their first experience. Hence in every way $I$ do think it is our duty, especially in a small Army like ours, and with a rich nation such as. we are, that we should get the most perfect weapon we can for the few' troops we can afford to put into the field-few as compared with those of other nations. I think the question of using the automatic rifle should be very seriously considered. We should not wait for somebody else to bring it forward, but we should try and find out for ourselves as soon as we can how to get a good automatic rife, combined with a lullet that will unfailingly stop any kind of enemy. Let us give up the idea that we must not have a mushrooming bullet-me must have it, and also a bullet with as low a trajectory as possible at all ranges. These three elements, together with the accurate and good manufacture of both rifle and anmunition, are the clief requirements for a military rifle, and not merely those necessary for a rifle for target shooting at Bisley.

Major P. T. Godsal (late 4th V.B. Oxford L.I:) :-I am sure we are all very much indebted to IIajor Fremantle for having collected for our instruction such a mass of detailed information about such military rifles as have been adopted by the various nations of the world, and I also thank him for having mentioned my own rifle. The lecturer has not summarised the conclusions to be drawn from the numerous facts that he has laid beforn us, but I gather that the questions with which he concluded his admirable lecture were intended to invite his andience to draw suci conclusions for themselres, as the facts seem to rarrant, so that we mas be able to help one another to form rational opinions as to the problems of the near future. It is interesting to hear what other nations are doing, and consolatory to know that in some details other nations have done the same as we have, but the most serious point in the whole lecture is tho fact that in the important matter of strength of brech mechanism we are hopelessly outclassed by other nations, more especially as ans further improvements in ballistics are dependent upon a strong breech nechanism. The time was when the rifle makers of England used to show the way, to lead and not to follow, and $I$ am sure that if the slightest encouragement were giren to them they would do so again. At any rate, our military advisers are leading the world in their absolute demand for a shorter and lighter rifle. But, judged by the new short rifle, there is a lainentable lack of capacity on the part of our rifle designers. The only way to shorten the rifle that they ean think of is to cut 5 inches off the barrel, and the only way to further lighten it is to pare down the barrel. Beyond this we have but a fer unimportant details to record, and the only real picce of original design of which we can boast is that wo have cromned the bolt-head with what can only be described as a sliding outrigger called the charger guide. The breech mechanism still remains a mere conglomeration of compromises, garnished with makeshifts, a poor sort of affair to spend 3 millions on. It is dependent upon superlative excellence of manufacture for its working at all with safety. By a compromise I mean a piece put into an action for one purpose and made to do for another, for which it is not suited. By a makeshift I mean 
a pieco put into an action to prevent another piece going wrong. The time has come, as I am prepared to prove, when compromises and makeshifts should be abolished, unless it can be shown in particular instances that any particular adrantage accrues from their use. After long consideration and much practical experience, $I$ have come to the conclusion that we have perhaps, the best barrel and an excellent cartridge, but the very worst breech action, and we shall never get a really effectire rifle until we have a breech action that is capable of doing justice to the barrel and cartridge. The characteristics of our action are weight, weakness, and complexity, entailing mutilation of the barrel to relieve weight and reduce length, reducing of the charge to spare the weakness, and complexity entails great expenditure. The facts all point to the breech mechanism being the crux of the whole question. Although no nation is completely satisfied with the breech action it has adopted, yet the lecture brings out very clearly the fact that we are far to the rear in the march of progress since it is becoming universally recognised that a front-locking-bolt is necessary, as nothing less strong will resist the pressures that must be dereloped if the full ballistic power of the barrel is to be got out of it. But I appeal to the unsphisticated judgment not only of nations but also of individuals. No nation will look at our rifle action, and no individual, either (excepting so far as he is influenced by the fact of its being the service weapon). The consequence of this is that the service rifie is lilling the rifle trade of this country, and acting as an incubus on progress, since no one can afford to tako up an improved military rifle without some sort of Government support. But I do not hold with empty criticism without suggestion, although candid criticism has its uses, as the first step towards getting a want supplied is to show clearly what is wanted. But I havo always preferred suggesting to criticising. My suggestion is, that wo approach the question as a definite mechanical problem, capable of a definite solution. Do not let us go looking round to see what the others are doing, like a school boy trying to crib at an examination; let us make up our minds that we will have no compromises and no malieshifts. It is perfectly easy to mako a rifle action without any compromise or makeshift about it, and that instead of being the reakest shall bo the strongest; and instead of being one of the heariest, shall be far and away the lightest; and above all, much the cheapest and easiest to manufacture. Do not go fussing about the future, and whether we are to hare automatic rifles or not-that is putting the cart beforo the horse. Depend upon it, if we are to have antomatic rifles the first essential will be a sound breech mechanism to make automatic. Face the problem boldly, and sou will find it perfectly easy of solution. I haro done so already, and I shall be pleased to show you how to make a military magazine rifle without a compromise and without a malseshift, stronger, lighter, and cheaper than any other, and that will enablo you to shorten the rifle without mutilating the barrel, that shall feed cartridges into the magazine and eject as well as our present service rifle, and that although it is best made with an undivided stock, yet it can equally well be made with a divided one, so as to use up the wood that we now have stored for the purpose. If anyone wants to sce a rifle of this class $I$ shall be happy to show them afterwards, as I have one in the Museum. It any rate, I hope that this meeting will demand fair play for English inventors, more especially when they undertake themselves the labour of designing and improving their om inventions, and bring formard a ner principle of rifle construction. Do not let it be said that England must go on her knees to foreigners to get them to 
'design arms for hor soldiers. The powers that be will incur a very serious responsibility if they insist upon forcing our soldiers to drag about with them rifles that are more than half-a-pound each heavier than they need be, at the same time that they have the weakest action adopted by any first-class nation, when the sirongest action is half-a-pound lighter. If there should be any that could not stand the kick of such light rifles (though it would be far less than that of the Martini), let them have their rifies weighted, but do not forco 090 men to carry lalf-a-pound extra because 10 men cannot stand a mild kick from their rifles. There is no reason why rifles with the long barrel should not be reduced in weight to $81 \mathrm{lbs}$., and with the short barrel to 71 lbs., and the length in each case bo reduced by 41 inches. It any rate, I do lope that this meeting will not disperse without demanding fair play for English inventors in general, and English breech mechanism designers in particular. It is no child's play to design a breech mechanism from start to finish. Let ansone try it and sec. But the designing and perfecting of a new breech mechanism has this effect, it makes ono who has made the effort, feel very charitably and sympathetically indeed tomards all those who have had a share in the rery arduous and onerous task of proriding a small arm for his country. I know as few men can what a difficult work they have had, and I feel absolutely certain that under very difficult circumstances they have one and all done their best. But they each and all lacked one essential, they all wanted time and opportunity to sit domn and quietly study the problem as a whole. I have been able to do this, and I feel sure that if there are any defects in my work they are due to immaturity of design, and not to unsoundness of principle.

Lieut.-Colonel Iror Phiciprs, D.S.O., 2nd in Command. Pembroke Imperial Yeomanry (late Indian Army):-I think we should all be very much indebted to the lecturer, for the clear way he has stated all the essential points of a modern military rifle: I think the last few paragraphs really contain the crux of the whole question, namely, those in which he considers what the rifle will be in the future. Surely the new short rifle has not one single essential point that the lecturer considers a modern rifle onght to have. 1 think $I$ am right in saying that it has not got the relocity, the calibre is larger than he recommends, the lugs are far back on the bolt and not in the front, as they should be, which necessitates low pressures, limits the porer of the cartridge, and, in fact, generally limits the fire of the rifle. He shoms us that, with the exception of the Portuguese rifle of 1886 and the Danish rifle of 1889 , the new short rifle is the weakest rifle in the world. I do not think it is very creditable that a great country like England should now start making a new rifle that is actually weaker than the riflo Denmark and Portugal adopted 20 years ago. I do not think anything much worse could be said of the new rifle for this country than that. Again, wo still stick to tho old rim cartridge, while everybody else has adopted tho rimless cartridge. The Japanesc, with their usual intelligence, havo adopted a semi-rimless cartridge, thereby getting all the benefits of the "rim" and of the "rimless" cartridge. The supporters of the new short rifle appear to me to have very little to say in its farour. The most they can say is that it is as good as, or nearly as good as, the old one. Surely after all these years we might go a step further! The supporters of the Jee-Fnfield say : "Olh, the Boers liked it; it must be a good rifle, because when the Bocrs got hold of it they alrays used it in preforence to their Mausers." I think that is a very reak argument. Everybody knows that all service rifles wear ont, and many of the Boer 
rifles had been a long time in use. Then it is well known that the Boers wero very often short of ammunition, and unfortunately they managed to get hold of a good deal of our men's ammunition. What was more natural, under those circumstances, than that they should also use our men's rifles when they fell into their hands? I think it is quite possible that at the present moment, when the Japanese are pursuing the Russians hard and fast, many of the victorious Japanese are using Russian rifles. It is quite within the range of possibility that the advanced Japanese troops have got beyond the limit of their own ammunition supply; and is it not therefore possible that, as they have captured a great deal of Russian ammunition, they may be using Russian rifles? But that would not be an argument that tho Russian rifle is better than the Japanese. It is feeble arguments like that which are brought forward in support of the new rifle. If the Suall Arms Committee recommended the new rifle as the best rifle obtainable, we should then know that we had an expert body of men who guaranteed its superiority; but we are specially told by the military authorities that the Snall Arms Committee were not asked to select a new rifle or recommend the best obtainable, but were told to improve the present rifle. Lord Roberts made the remarkable admission in the House of Lords that the Small Arms Conmittee could not have taken up the question of a new type of rifle if they had. wished to do so; Colonel Ian Hamilton's Committee was formed to consider and report on the best practical method of lightening the present rifle. I maj be wrong, but $\Gamma$ believe there is no evidence before the country that our leading soldiers have considered the question of a new rifle or of the best rifle obtainable, but only the improvement of the old one. We know that Lord Wolseley was dead against the shortening of the barrel as far back as 1898. Six years afterwards we are going to do what was condemned then. I think that alone is enough to condemn the present scheme. No attempt has been made apparently to find ont if there is a better rifle on the market. That is the whole point. I may be wrong, but I believe there are better rifles on the marliet, and $I$ believe that is the opinion of all those who take an interest in the subject and examine the question in an impartial manner. I think they will agree that the breech mechanism of our present rifie is not $\mathbf{a}$ good one. It is a makeshift, and it always was a makeshift, and no tinkering with it can improse it.

Lieut.-Colonel F. N. Maude, C.B., p.s.c. (late R.F.), O.C. 1st Hants R.E Vols. :-I should like to take this opportunity of supporting overy word that Colonel Mayno said on the whole question of rifles. It seens to me a pity that in an Institution like this, when a question of this sort is under discussion, that somebody at least shonld not rise and make a protest against the wholesale way in which anything that is proposed in the way of new armaments is invariably condemned by the Press. In the field, the adrantage of superior handiness and lightness far outweighs all considerations of target accuracy, and we have gone too far already in the sacrifices to man-killing power we have made to secure such extreme accuracy, which, under the rough usage all war weapons must expect, is very soon lost in practice. If I had prepared myself to speak on the subject I could have given a number of figures to show some of the extraordinary things that have been happening since we got these new nigh-relocity long-range rifles with small bores; but, roughly, you may take it that whereas in the Franco-German War it took about 1,000 rounds of the Chassepot to place a German out of action, in the Boer War 
$t$ took about 10,000 rounds of the Lee-Metford to disable a Boer. So hat you therefore have the curious fact that though you have an actual eduction in the weight of the cartridge of about 50 per cent., you have $o$ use ten times as many cartridges to get the same result. It would take oo long to work out that problem now, but I think if anybody will talse the rouble to go thoroughly into it, they would find that from the point of view If collective mobility what we want is a more powerful rifle with a big ;mashing bullet, which would actually transmit tho ballistic effect generated $n$ the barrel to the body of the person for whom the bullet is intended. What object can there be in having rifles which develop so much ballistic power and conrey it up to so many miles distance, and yet fail to bring Jown the horse or man you want to stop? There are many here who probably remember thmed Thel in 1879, and probably some who can cecall the different appearance presented by the fronts of the lines where the British troops stood with the Martini and where the Silks and the Gurkhas stood with the Snider. An eye-witness told me afterwards that the Snider bullets stretched the enemy out in swaths, dead, but the other bullet hardly stopped them at all; they came on and died afterwards. That was not what we wanted, we wanted them to die then. High relocity and flat trajectory are not the only desiderata in modern military rifles; what we want is a bullet that will do its work and kill.

Major F. E. VARLeY, H.A.C.:- Major Fremantle has so well covered the ground of the subject of the lecture that $I$ an afraid I have not very much to say; but he did not refer to the possibility of the introduction of another sight. I believe with a large aperture sight you will produso a rifle that would gire great rapidity of aim. I do not think the present sight is by any means the end of military sights. What I more particularly rose to refer to was the somemhat scathing remarks of the first speaker on the subject of the tests carried out at Bisley. I was one of the seren gentlemen asked to test the gun, and I think he rather misunderstood the view we took of it. Compared with the long rifle, we found it to be a less handy weapon; it is too heary in the nose, and we found that the sight protectors that the author referred to were very balking for taking rapid aim. Te also found it less accurate and less hand 5 , and the kick is greater. It is not materially greater to any man who can handle a rifle, but anybody who has spent a number of years, as I hare, as an instructor will know the enormous difference it makes in teaching a man to shoot. As regards the number of rounds fired in active service nowadays, I do not think that at any time during the Boer War, where the rifles were really well handled, anything like the number that the speaker mentioned were used. I will put it to the meeting that at the present moment the Russians are using the morst ammunition in the rorld, so far as my experience goes, and they are alsolutely the worst trained Army in the world from a musketry point of view; in fact, there is hardly a man amongst them fit to fire a rifle. If you go back in history you will find that the British infantry has always been recognised as about the fincst fighting unit, and really their efficiency has depended on two points : the coolness and the accuracy with which they handle their wenpons. Fren going hack to the time of the long-bow, it was almost as effective at 100 yards in the hands of an expert archer as a magazine rifle; in fact, tho damage they could do was so great that they were practically invineible. So it was right through the Peninsular War. You will find that tho English infantry was traincl to target practice, and traincl to handle their weapons in times of peace. If you read history you will find that 
the men who fought under Napoleon all over Europe when they were brous it against British infantry were staggered with the accuracs of their iire. Owing to the power they acquired of handling their weapons they acquired a confidence which allowed them to wait until the enemy was within easy striking distance, when they could make the fire effective, and that is the great argument for accuracy. The first speaker adrocated accuracy, and then he said it was impossible; and at the finish he said the great advantage of an antomatic rifle would bo its further accuracy. But I do not think that is the question. The point that is uppermost in $\mathrm{my}$ mind is that tho great number of rounds fired in the present war is simply due to the fact that the people who are using the rifles do not know how to use them.

Major-General Sir E. T. H. Hutrox, K.C.M.G., C.B. :I do not hold a brief for the War Office, nor do I propose to enter into a controversy as regards the adrantages of the rifle that is to be or the, rife that is; but $I$ would like to remind this meeting, at any rate, those present who are as old as myself, of the controversy that took place orer the adoption of the present 303 rifle. If they comparo the comments, and, above all, the leading articles in the Times in 1889 on the subject, with those that have appeared lately, they will find that practically the self-same arguments were used against the adoption of the -303 magazine rifle then that are held now against the adoption of the new shortened rifle. Not only are the public very reads, but $I$ think perliaps my military comrades are cqually ready to criticise anything now. Whatever may be the merits or demerits of the new rille, we may be quite certain of this, that it has only been adopted after most careful thought and after most careful tests. If Colonel Mayne will allow me I should like to make one or tro comments with reference to the able and interesting remarlis he has made upon the paper. In the first place, with regard to sights, he has stated that it is his strong and firm belief that the nearness of the sights does not affect the accuracy of shooting. Whatever it may do at a range and at a target, it very materially affects the accuracy of the shooting in war, under conditions of active service, and above all during the critical time of a fight. I feel sure that those present who, like myself, have been often in action, will endorse what $I$ sas in that respect. This I know for certain, that in the Boer War of 1881 , when it was $m$ privilege to serve with a mounted infantry corps armed with carbines, there was some misapprehension on the part of some authorities at home of the ralue of a long rifle. Our men on the spot were fully aware of the fact that they were armed with an inferior weapon to their opponents, and at the commencement of every action they had that instinct which it is nost unfortunate that soldiers should have, namely, that they irere armed with an inferior weapon to that of their oppoinents. The principal reason which made the carbine an inferior weapon to the rifle for use in action was, in ny judgment and in the judgment of most soldicrs, the nearness of the sights together. The lecturer has told us that the sights in the new rifles are only 19 inches apart. If that is so, I think that it is a very serious detriment to the advantages of the new rifle in regard to battle requirements. I also most strongly endorso the views which Colonel Mayne has given as regards the automatic rifle. It was certainly the hope of many of us, certainly those who wcre associated with me recently in Australia, that we should see in this country a great development in the use of the rifle, and that in place of Great Britain seing content to follor Continental Powers in the matter of rifle power, we should take the lead. 
To follow, after all, is to be left behind; and we did hope in Australia, where these things are very closely considered and very carefully discussed, that as a change was to take place in the small arm that was to be used in the British Army; that an automatic rifle would take the place of what we know now must in a very short time be superseded. I am quite at issue with the view that Major Fremantle has stated in his paper as regards the basonet. I am not aware that the sword bajonet has provel the success which he claims'for it. The question is, what is the bayonet for? Is it a reapon of offence and for thrusting purposes, or is it a general utility weapon of the character of a hunting-knife? If it is to be used as a weapon of offence, I claim that the present. sword bayonet does not sufficiently well fulfil its purpose. Perhaps I may quote.from my own experience. I was in 1881 in Cairo organising the Mounted Infantry Camel Regiment, for service in the Soudan, and in organising that regiment $I$ had carefully selected detachments from all the different infantry regiments in Egypt at the time, and many who were at home. I consequently had among the men an enormous number of soldiers who had seen a good deal of active service. New rilles wero issued to us with the old sword bayonet, which in many respects, as you are aware, is much like the present sword bayonet. Within a few days after those rifles and bayonets had been issued I was asked by $m y$ adjutant if $I$ would receive a deputation from some soldiers who wanted to malio a representation to me. I agreed, and three sturdy old soldiers, who had served in three or four campaigns in the mounted infantry in different parts of the Enpire, appeared. It transpired that they came to report, on the part of their comrades, the fact that the sword bayonet was a weapon which was entirely inapplicable to the purpose for which they understood the bayonet was given to soldiers, namely, to kill their enemy. In their homely language they explained that they "could not get it out and they could not get it in." Gentlemen, I fully sympathised with those old soldiers. I' recall the magnificent work done by the Highland Brigade at the battle of Tel-el-Kebir witl the old bayonet. The bayonet work they did against the Nubian regiments, only those who were there at the time could possibly picture to themselves. With regard to Colonel Mayne's remarks in reference to mounted troops, it has been $\mathrm{my}$ good fortune in the last $2 \tilde{5}$ years to be concerned in the organisation and in the leading in peace and war of mounted troops in various parts of the Empire. I feel sure of this, that the next great development of the mounted troops will be that they will be armed with an automatic rifle, and that that automatic rifle will be provided with $a$ rapier bayonet. I hold that mounted troops so equipped will form the most formidable arm for offence and also for defence that it is possiblo for modern military science to employ. I do not suggest that the rifle will be fired from the shoulder, but horizontally from the side, as we hare recently been doing with the Iustralian Light Horse. Tie shall see, I anticipate, within a fer years important developments in regard to the handling of mounted troops. Wo have yet to realise the cnormous porrer we possess in mounted troops, armed with good riffes; and the development indicated will, I renture to prophesy, be adopted in the very near future. I entirely corroborate what Colonel Mayne has said as regards the action of the mounted troops during the South African War, and I may also add that recently in sustralia we have heen carrying thoso tactics into effect. The squadrons and regiments of the Australian Jight Horse have been firing mounted with fixed bayonets, and have been trained to charge and to close with the enemy in that manner. 
Mr. Jonx Rigny :-The fact that has struck me most in connection with this lecture is that such a rich nation as ours. cannot afford to arm the few hundred thousand men it possesses with the best arm in existence. In this respect we cut rather a poor figure compared with the Germans, who rearmed their enormous forces with a new rifle-the Spandan-about the same time that we adopted the lee $\cdot 303$. In 1898, only ten years after, thes did not hesitate to supersede the Spandau by a new pattern, embodying all Mauscr's inprovements. The British Committec which has been sitting for some years appears to have been instructed that it was only to alter a rifle which was known not to be up to the mark compared with the latest arms in Europe. To show the activity with which the arm manufacturers in Europe pursue their calling, not only in making guns but infantry rifles, I glanced through the English gun patents this morning, and I found that just about the time General Smith's Small Arm. Committee was sitting, and had decided to adopt the Lee-Metfordwhich was just before I had the honour of being elected to the service of the Crown-in the sears 1837 to 1890 inclusive, Mauser took out twelve English patents for improvements in rifles, and a further two in 1891, so that altogether he took out 14 Linglish patents in five years. Some of those patents embodied important improvements in the Mauser rifle, which has held a premier position in Europe from that day to this. . Those patents have expired in England by eflux of time, 14 sears. Consequently a Committee meeting now would be able to utilise, without infringing any of tho patents, some of the most important improrements that have been made since the Lec-Fnfield rifle was adopted. I remember very well when the Lee gun was before the Committee that several rifles were submitted to the Committee by different Suropean manufacturers, French, Austrian, German, and others. They were all heary, clumsy reapons, some of them up to $10 \cdot \mathrm{lbs}$. in weight; but in that particular year and the following year improrements were made in the bolt and in the lugs; the Mannlicher and the Mauser people both introduced improrements. It has been a disputed point as to who invented the bolt with lugs in front, but that does not matter; there they are for anyone to use. I have always noticed a very great unwillingness on the part of our Government to touch anything which involved paying for patent rights; but the action it took in the case of the Lee-Metford rifle was about the rorst, in my opinion, for manufacturers in this country that could possibly have been chosen. They decided to pay a sum of $£ 50,000$, I think it was, to the Americans who had liens on Isee's patent, and then to allow those patentees who had taken out English patents for modifications adopted by the Committee, to put on any fancy royalty they chose, as against the general public or foreign buyers. The consequence was that it was impossible for manufacturers to place a large contract. Even then, when the Lee-Metford rifle was in very good odour, it was impossible for the Birmingham Small Arms Company or any other Company in fact which chose to embark in the manufacture of rifles, to place those contracts at a price to compete with the Belgian or German manufacturers. The patentees, who had not been fully satisfied by the Goremment as against the whole rights of the patent, insisted upon the payment of something like $14 \mathrm{~s}$. per rifle for royalty, which the manufacturers had to pay on every rifle (except those made by Government) and to charge with its proportionate profit in their estimate for the supply. Conseguently, when enquiries came from different places, such as Mexico and Peru, they found that the English price for the Ice-Metford was something like 25 or 30 per cent. higher than the German price for rifles 
with later improvements. There will be a demand in England, and probably in the Colonies, for the new rifle. It has been publicly stated that contractors for their manufacture have been forbidden to supply any to the public until certain patent rights held over them have been adjusted. I sincerely hope that this adjustment will remedy the state of things I have described, and that whatever pattern of rifle may be adopted in future or now, the War Ofice will acquire the patent rights on such terms as will free the British manufacturer from any further payments to patentecs.

Major Gods.lL :-The last speater stated that it was a question whether the Mannlicher or the Mauser people were the first in the field with regard to front-locking bolts. I beg to say that my rifle was used, in the interests of the Mauser Company, to prove that an Englishman had been the first to adopt front lugs, and so that the claims of both had been forestalled.

Major the Hon. T. F. Fnemantle, in reply, said:-I think it is. a great presumption for a man who not only has never scen action, but who is not cren a Regular soldier, to have read a paper on what is essentially a technical military subject to such an audience as this. I am very grateful for the kind way in which the lecture has been received. Nothing could have been more interesting to me than to hear the comments upon it which have been made this afternoon. Perhaps, I may bricfly allude to one or two of the points which have been raised. Colonel Mayne spoke of the question of having a good sectional density of the bullet for flight. J. thought I had made it clear that we all assume that to be a first necessity of any military cartridge in these days; as a matter of fact, there is not very much difference between the cartridges of the various Powers in this respect. I have never been into the question of the number of foot-pounds which it takes to raise and lower a rifle several lundred times in a day for aiming; I think that that cannot be a very large proportion of the whole work that a-soldier has to do in a long day's fighting, in which he fires 300 or 400 rounds. There is one difference of weight between our Iong and short rifles which comes in, and that is, that you do not now carry the oil bottle and the pull-through with the rifle, and that makes a certain reduction. With regard to the number of rounds that a soldier should earry, it seems to mo that military opinion would be rather divided on the suggestion that a soldier should only carry 50 rounds. It is a matter on which $I$ am not in the least competent to speak, but I should have thought that modern experience pounted to our carrying more rounds than that. As regards the question of accuracy, I hope I should be the last to wish questions of ideal or theoretical accuracy to interfere in the least with the practical utility of a reapon. It the same time, I think it would be quite wrong to introduce unnecessarily anything like a cultivation of conditions that tend to inaccuracy. I think that, just as the pace of the caravan has $t$ ( be regulated to that of the slowest aninal with it, so the quality of your military arm should be regulated to whatever can be got out of it by the most skilled men under the best circumstances in which he may have to use it upon service. With regard to the question of bayonets, which Sir Edward Hutton raised, I an quite unable to say on my own authority that the knife bayonct has been a success. He thinks not, and he thinks so, it seems to me, largely as a consequence of criticisms passed by those whose experience was an experience of savage warfare; and of fighting even, perhaps, against sworls in the hands of infantry. That, 
again, I think, is a question upon which military opinion would by no means go unanimously with him, and I look with the greatest possiblo interest to the Russo-Japanese war in that respect, whero on one side you have a triangular bayonet exaggeratedly long, and on tho other you have a moderate knife bayonet. As regards automatic rifles, my riew is briefly this, that until somebody has managed to solve the difficulties of creating a simple but efficient automatic loading mechanism, such that it really does meet the requirements of a military arm, we must perforce be content with doing without them. So far as my limited knowledge of antomatic rifles goes; I do not see that wo have arrived at the point, or that we are quite close to the point, at which such a rifle would be practicable for use by troops. I must confess that after hearing what has been said this afternoon about the great number of rounds which it takes in these days to kill a man in battle, I have been very much surprised to hear the suggestion that there should be firing from the hip either with or without an automatic rifle. It is, I think, a matter of great dificulty to know at what noment you should abandon your old pattern of brecch mechanism, and go in for the expense of an entirely new rifle; because the setting up of new machinery for maling a new pattern brecch action entails an expense rastly in excess of that which is necessary if you only modify existing designs in certain details. I am not competent to speak with accuracy of the figures which would be involved, but undoubtedly the difference is rery considerable. In conclusion, I should like to thank $m y$ audience for the very hind way in when they have listened to my paper, and for the equally lind criticisms which have been passed upon it.

The Charrus (Major-General Sir Thomas Fraser, K.C.B., C.M.G.) :We have seldom had a lecture so clearly expressed, and which contains such valuable facts for ereryone who is interested in the subject of rifles, than the lecture we have heard this afternoon. It will cnable the people of this country to judge for themselves about many of the questions connected with small arms. My few remarks will be confined mainly to one point which is interesting the country and the Army at the present moment, namely, are we right, pending a serious re-armament, in adopting the short rifle that is proposed as a temporary measure; instead of adhering to the old one with necessary improvements? Lord Roberts, with his usual lucidity, explained in the House of Iords the other day, what really had happened. Some years before the war, an attempt was made, and most fortunately failed to substitute the L.-M. shori carbine for the L.-M. rifle, for infantry as well. What led to it was the fact that with the new powders a substantial muzzle relocity can bo got with a short barrel. After the war, it became evident to everybody that the state of the barrels of our rifles was such that we must very speedily replace them, and that the sights must be improved. What also became evident to everyone after the mar, as it had been evident to some of us before, was, that it was impossible to go on without bringing our rifle on a par with rifles of other Armies in the matter of quich-loading. Among other things, it was thought it mould be rell to have only one rifle for cavalry and infantry, because it was supposed that the cavalry could not carry a long rifle, and because it was more convenient for supply to have only one pattern. There was also the notion that a shorter and lighter riflo was more convenient for British infantry; while the grave question of the barrel vibrations, disclosed by recent photographic experiments, might also be dealt with at the samo time. ill those points led to the idea that it would bo quite a simple matter 
to shorten and improve the rifle; and that, instead of improving the Service arm, wo could, by using machinery already existing, quickly get a short rifle that would fulfil expectations and that would meet our wants, till tho next re-armament. But, as time went on, it was evidently found that difficulties occurred with the short rifle itself. A number of arrangements had to bo made to get over theso difficulties. It did not, apparently, act as well as was expected, and shifts had to be gone through, and new machinery had to bo made, all of which involved delay' before the short rifle was brouglit up to a condition which was thought to justify its replacing the Lee-Metford. Were we wise to make this change, which involved us in a costly rearmament, and one of a temporary nature only, in addition to the delay of two years? Had the short rifles been at once tried under identical conditions (of improred sights, same muzzle velocity, vibrations of barrel, etc.), with new long rifles, both in the hands of the troops and on a very large scale, it is a matter of opinion what the result would have been; but we would have learnt where we wore going, and could hare set the gain, if any, against the cost and time of rearming. We have, however, lost a great deal of time. An early form of this short rifle, admirably siglited, better protected against vibratory disturbances, admirably fitted, much better than rifles turned out in the gross are fitted, was apparently tried against the Service rifle in tho hands of the troops, when the barrels of the rifle must necessarily lase been in a very poor condition. There can bo no question whatever, the Service rifles in use had worn barrels, we cannot say how worn, but at all erents, to a certain extent; barrels that had sights of a pattern very inferior to the sights put on to the short rifle, and sights that, it was found in the war, were also badly adjusted indiridually. The Field-Marshal stated the result of the trials was, that the one shot about as well as the other. Many soldiers and riflemen think that with the longer barrel the man shoots better than with the short one. For, whatever devices are used in the position of the sights, the possible distance between them varies as the lengths of the barrels. They may be quite wrong, but no reliable eridence exists in this case. All that is necessary is to show that the final short rifle tried under identical conditions of improvement with new L.-.Mr. rifles, equally well finished, shoot so much more accurately than the other as to justify the extra cost. The saring of weight is only that of the 5 inches cut off the L.-2M. barrel, say 6 or 7 ounces, but erery other method of lessening the weight of the short applies equally to the long rifle. It seems regrettable that that was not done, and desirable that it should be done now, before the infantry is rearmed. There are other not unimportant side issues, but this is the main one. We have to think of the confidence of the troops, and nothing short of an effective comparison will secure that. In peace, of course, men would prefer to carry a revolver instead of a rifle. A remark was made here, I am sure inadvertently, rather derogatory to gentlemen who so kindly came forward and assisted at the recent Bisley trials. Many of us think it is a very important thing in this country that private sportsmen and marksmen should take an interest in so important a national question, though the proper test of a military rifle is its exhaustive trial in the hands of the troops themselves. We think, also, that it is very desirable the Press should do so as well. In my opinion, the country orres a great debt to the Press for taking up this question from an outside point of vicw. Tho very pleasant task now devolves upon mo of proposing a hearty rote of thanks to Major Fremantle for the extremely able and interesting lecture which he has given us. 


\title{
THE VOLUNTEERS IN 1905.
}

\author{
By Colonel the Right IIon. Sir'J. II. A. MACDONALD \\ (Lord Kingsburgh), P.C., K.C.B.
}

Tuesday, 11th April, 1905.

Colonel Lonsdate Hate, late R.E., in the Chair.

FORTY-SIX-years have passed since the month when the first Volunteer was enrolled in 1859. It is quite certain that no one, from the Secretary of State for War down to that humble recruit-whoever lie was-had the slightest conception of what the Force would become which then, at the first word of official sanction, sprang into existence. There can be no doubt that it had its origin in a genuine movement of patriotic feeling, roused by the attitude of menace taken up against us in a certain military circle abroad. As a demonstration, it could not have been more effective. Everywhere there was enthusiasm. The eurolments became from day to day more numerous, and before many months had passed there was not a town of any. great size which hád not its battalion, and every country town had its company. The idea then was that the Volunteer was to be one who not only sacrificed part of his spare time, and of the enjoyments of home and social life, to prepare for the defence of his country; but that he should find the money to clotho and equip himself, and pay out of his own pocket for the weapon served out to him, and the ammunition to be used with it. In short, while saving the country from compulsory military service by willingly undertaking duty for others, he was to be permitted to do tlie duty-to quote the words long familiar to me by constant reiteration, when I was allowed from time to time to go to Aldershot for special training-"This permission is given upon the distinct understanding that his doing so is not to involve any charge upon the public service."

Such a state of things was probably unique in the history of the world, that a general call should be made upon the patriotism of the nation, and that those who responded should be required to find for themselves the things needful for the fulfilrsent of the service, and those who did not respond should go scot-free; that the worker should be taxed, and the drone left with his money in his pocket, to spend on his pleasures. There is no other nation in Europe in which the official mind, and the public mind, could, or would, expect success for such a scheme. The result was that at first the enrolments wero chiefly among the well-to-do classes-lawyers, baukers, merchants, civil servants, and, in the country, squires, farmers and tradesmen. But the artisan was not going to be excluded. The working men came 
forward in large numbers, and made, what for them, were greater sacrifices than those made by the middle and upper classes. Let me give an illustration from my own experience. I remember well the first four companies of artisans being enrolled in my own city of Fdinburgh. It was the converse of the taking of the Queen's shilling, and a pretty handsome converse, too. Every man asking to have his offer of service entertained had to bind himself to pay £1 10s., of which 10s. were required to be put down before he could be sworn in. Notwithstanding this, in the course of a year, the number of artisan Voluntecrs increased so greatly that the corps ran up from 8 companics to 16 , then to 18 , and ultimately to 25 , of which at least two-thirds consisted of working men or men whose means were as meagre as those of the artisan. The remainder of the money necessary had to be sought, for by expedients-bazaars and fancy fairs, theatricals and subscriptions extracted by dunining the charitable, etc., etc. Again I say that such a mode of keeping down the estimates for the expenses of the public service would have been impossible in any other nation but this. When such sacrifices were made all over the country, it was a testimony at the time that these men svere in earnest, and if the Force gradually rose to the 250,000 which we are now told is too many, it was the fruit of that first self-denial by which alone the Force in its early days obtained the stability of perseverance which finds it within sight of its jubilee, numbering a quarter of a million of men-men who, whatever may be said about their physique or their training, are a living symbol of the spontaneous patriotism of the race, which in others who do nothing for the pational defence is, we shall hope, only dormant, and will wake into life, should the day of peril come. For, although we detest militarism, we are a martial race by nature.

The Force has come through many phases, and has survived them all. It had its "spoiled child" phase, when it was petted and flattered, probably the most dangerous to its welfare of all through which it has passed. Then came the time of reaction, when the upper and middle classes had ceased to crowd into the ranks, and when with few exceptions it was left to the working men to fill the places which the well-to-do had vacated. It was then that it began to dawn upon the official mind that a state of things could not continue in which a Force consisting mainly of poor men and young officersthe great majority of both just entering the battle of civil life,should not only give up their time and much of their legitimate family comfort and social enjoyment to serve gratuitously for the rest of the community, but should be heavy losers in purse for doing so. The burden, particularly upon the officers, was becoming intolerable, the Force having been allowed to fight its own way for several years, the only expense to the State being the providing of inspecting officers and adjutants. Uniforms were beginning to become unserviceable, and had to be replaced; the expenses of head. quarters and ranges were great, and the general public, who, in the person of their generous members, had contributed largely in the first instance, could not be called upon again to do, as individuals in unreasonable measure, what, if the Force was worth maintaining it all, was plainly a national duty. The public generally had ceased to take any real interest in the movement, and indeed in many cases employers and parents discouraged young men from entering

voL. XItTx 
the Force. The men of position who at first had taken commissions to encourage others had gradually disappeared, many of them being quite unfit for practical military command, and it had fallen to younger and poorer men to take up the duty. $U_{p}$ to that time many officers did the whole drill and musketry work of their companies, without any Army instructor's' assistance, and did it well, qualifying themselves by diligent study, and sacrificing many a social pleasure to devote their cvenings to drill, and their half-holidays to musketry. If the records of those days were to be turned up it would astonish many to know what earnest and full-hearted work was done. I have often myself attended three drills a day, two learning with other companics and the third drilling my own, and the old roll-book of my. company recorded many attendances of the men at 70 to 100 drills in the season from November to July. Of course, at that time the Volunteer was very seldom taken seriously, either by the Army or by a great proportion of the civilians; indeed, there was not only "damning with faint praise," but many a sneer to be endured. Every defect in the individual was pointed at as characteristic of the whole. A drunken or disorderly soldiel-well, he was an exceptional disgrace to his corps. A drunken Volunteer was held typical of the mass-he was a proof that the whole force was undisciplined and useless. If an Army colonel clubbed his battalion, or his captains bungled a deployment, it ras a mistake, and that was all. If such a thing occurred in a Volunteer Corps, military shoulders, went up and the crowd jeered. I remember well on one occasion of a sham-fight at English manœuvres hearing a C.O. of a Volunteer battalion roundly abused by a staff officer for bungling, and the contemptuous phrase, "These Volunteers," fiung at the corps, then and now one of the best in the Servica, and I, being on the occasion only a spectator, with difficulty restrained myself from informing the speaker that the Volunteer he was expressing his contempt for had only two years before left. one of the battalions of Her Majesty's Foot Guards with the rank of a field officer, and that his inefficiency was a cause of chagrin to "These Volunteers" who served under him.

There can be no doubt that this was the most critical period of the history of the Force. It was the time when conditions began to be prescribed to the Service. If a capitation grant was to be given, a test of efficiency was to be exacted as a quid pro quo. The nation undertook to meet the reasonable cost involved, if the Volunteer undertook to give a definite amount of work. This was at once accepted. Instead of exaction causing a falling off, the numbers increased, and the 105,000 of 1860 became the 250,000 of to-day. The Volunteer Force gradually took its place as no louger an experimental but as an integral part of the Forces of the Crown, and was gradually drawn into closer relations with the Army. And I have no hesitation in making the assertion that it is those officers of the Army who have been tirown most in contact with the Volunteer Force, who have the best opinion of its potentialities, and who took it "seriously," although it seems to have been thought in Pall Mall that it had never been taken seriously till the 2⿺th December, 1901. Of course, all recognise that the Volunteers are but rough-hewn material, and that a large proportion would require some time for extra training before they could be considered able to take their places in the front. But those who 
discriminate see nothing in this to the discredit of the Volunteer. It cannot be otherwise. It is in military matters what it is in all other branches of skilled athletics and marksmanship. The best individual amateur may be nearly as good, or even as good, as a professional; but the general body of amateurs cannot be up to the standard of the professionals as a class. Therefore, comparisons between them which are made by weighing them according to one standard are unphilosophical and stupid. The question is not whether Volunteers can compare with Regulars. The question is whether the nation gets out of the Volunteers all that it can reasonably expect from a Force which must be trained in hours taken from spare time, that others devote to family life and personal enjoyment, and which makes no gain by its service. If it does not, and cannot, then there is no question as to what should be done. The curtain should be rung down, and the farce, played under the stage management of Cabinet Ministers and Commanders-in-Clief, for nearly 50 years, brought to an end.

The nation and its advisers should face the question as one new and crucial-what is to be done to make provision for the national defence? If the Volunteer Force is a male-believe, although flourished by authority before the nation as a reality during all these years, the sooner it is out of the way the better, that the question of the national defence may be looked fair and square in the face. It is easy for Royal and Departmental Commissions or Committees to make reports and recommendations for compulsory training of the manhood of the nation, but it is quite a different thing for the Government or the country to entertain such an idea. We citizens know perfectly well that no such thing is intended to be done, or will be done, as to bring a Bill into Parliament to enforce compulsory military service on the community. We are a long way from that yet. The Volunteer may be good for little, but he is good enough to be put forward as a stop-gap, a means of preventing disagreeable and awkward subjects from being thrust before a Cabinet, and a solution of them demanded. The true problem is how the issue of straw may be kept down to please the Treasury, and soothe the taxpayer, while the tale of bricks which the Volunteer is called on to deliver is made more exacting and burdensome. The present question is-how near can the Volunteer be brought to the region of compulsion, without reaching the breaking-strain point?

What is the present state of matters as regards the Volunteer Force? Is it true or is it not, that it has progressed in efficiency for many years, that the proportion of officers who have qualified in those military subjects which are appropriate to such a Force, has largely increased, that during the recent war it-to the surprise of the military worldcontributed all it was asked to contribute for active service quite outside of its engagement, and at common soldier's pay, that its own officers were found able to lead their companies with credit, and to maintain discipline, that it contributed many officers and many men to new corps, formed for the occasion, and that these acquitted themselves to the reasonable satisfaction of those in high command? I speak from what $I$ lnow as regards my own brigade, and will appeal to the expressed opinion of the commanding officer of the Royal Scots as to the service companies sent out to him; and I have yet to learn that any general in the field has had 
to send in an unfavourable report against the Englisl or Scottish Volunteer, either as regards efficiency or discipline. On the contrary I feel justified in trusting much to the words of so high an authority as General Sir Thomas Kelly-Kenny, when he said:-

"The Volunteers joined their Line battalions with extraordinary quickness, assimilated all that was good in our regimental system, and contributed to it with their many fine qualities. They were intelligent and patriotic, and fell into disciplinary order at once. I found them throughout the area of the campaign, held in universal approval by the generals, brigadiers, and commanding officers, under whom they served, who frequently, by reason of their high training, their intelligence, and their physique, and their marksmanship, placed them in advanced positions, demanding special individuality."

Spcaking again of what I know personally, I am ready to take the deliverance of any of the seven or eight generals. under whom I lave done training at Aldershot for many years, whether in work done, and discipline exhibited, the Forth Brigade, who went there in large numbers, fell short of any standard which it was possible for a Volunteer Force to attain to. Of course, there were deficiencies, and there almost always must be deficiencies in troops intermittently trained, and often necessarily ignorant of many of the minute points which, in a Regular Force, are held to be the symbols of discipline, though often but poor exponents of discipline itself, which is a moral and not an external condition. But it is a complete delurion to suppose that the Volunteer objects to the exercise of firm discipline from officers who know their work. My experience is, and I know that it is the experience of all who have been long associated with the Force, that the company in which work is vigorous, and discipline firm, is the company that has recruits pressing into it, and that the units which fall away are those where the officer is, by nature or by ignorance, incapable of infusing the spirit of discipline. There is nothing the Volunteer in the ranks detests more than being made a fool of by his not being brought up to a proper mark in soldierly drill and discipline. If his officer can do it, he will submit to anything at his hands. It is its absence which brings about resignations, or deadens recruiting.

No one who has had long experience in the Volunteer Service can doubt that the question of maintaining a full cadre of efficient officers is the all-important one. The material of the rank and file is better on the average than is obtained by the Army recruiting sergeant, for which opinion I refer to the official statements of Lord Wolscley, Sir Evelyn Wood, and Sir John French, and many others well able to form an opinion. It is material that can be made good without difficulty, if the command, from the officer at the head down to the subaltern, is what it should be. And by that I do not mean that every officer must necessarily be what in a polite society sense is called a gentleman, which is a term often mucl misapplied. If a Volunteer officer has the instincts and the manners of a gentleman, although his station may not be such as would admit him to exclusive circles, he may be, and often is, a better officer than the man who, with a natural right by birth to call himself a gentlemar has never had to brace himself to a true life of usefulness. In $\mathbf{n}$ long experience $I$ have never known one case of a man who had at 0 time any steady occupation in life making a really good Volunteer officer. I know there are such cases, but they are very rare. It is 
your idle man who never can find time to do anything, and no truer word was ever spoken than that of Colonel IVestropp before the Royal Commission, "The busiest civilian is the best officer." The most efficient officers I have ever had under me were men who had much to do in civil life, and among these were many who, joining young, practically made their position as gentlemen by taking on an officerlike bearing, and finding satisfaction in the study of smartness of person and conduct. The private in the Volunteer ranks will never care who the father of his officer is or was, or what he is doing in civil life, if he knows the officer to act like a gentleman, and finds himself and his comrades to be smartened by his comniand and stimulated by his example. That such men can be found to command Volunteers, and command them well, I know by experience. They may be of little account in what is called haut ton, but they, though poor in money, and unrecognised in station, are gentlemen in the best sense. In my old corps, with its cadre of over 100 officers, I have never known a year in which there was more than an odd one or two vacancies, and often there would be several candidates waiting for commissions: and this without keeping up numbers fictitionsly by allowing any officer to hold a commission for which he was proving himself unfit, or nominating officers for commissions whose education aud manners were exceptionable. Many a man had to get a hint to go, as must be the case in all corps that have any true standard of efficiency, for nothing will do more to prevent young men joining as officers than the knowledge that men are in the commissioned ranks who will be above them, the state of whose commands shows decay and failure.

But it is certainly a deplorable feature of our modern national life that in a country, the most wealthy in Europe, where so many young men have no need to work for their living, and where thero would be an excellent field for their energies in a patriotic service for national defence, it is the rarest thing possible to find one who will make a small sacrifice for so good an end. How many welldressed and perfectly groomed triflers are there in this great London with brains atrophied by society small-talk and frames enervated by idle habits, who, if they could be roused to a sense of duty, aro capable of excellent service. It is all very well for Royal Commissions and lecturers and writers in magazines to keep harping on the theme that the Force should be officered by gentlemen, meaning thereby gentlomen borin. It would be much more to the point if they would tell us how it is to be done. This sort of talk which is fired off at the Volunteer officer who is, and made a matter of comment against the Force,-making the idleness of the absent a reproach to the active and the devoted,-reminds one of the clergyman who, having a very small congregation assembled, roundly rates those who are present for the sinfulness of those who absent themselves.

This has been rather a digression, but it is surely a duty, whenever an opportunity arises for speaking on the present topic, to raise one's voice in urgent entreaty to our idle young men, who, instead of using sport as a recreation, devote tl ir lives to it as a business making it a canker to their true eners is, if by any means they can have the spark of patriotism made co spring up in their liearts, kindling them with the fire of a new affection, causing them to give a small modicum of the time that they alone in the community have at their free command, to a generous service for the country's safety. 
What a difference it would make, and if they knew it what a real benefit to themselves, and with almost absolute certainty a welcome relief from the blasé state of the votary of mere self-indulgence. Alas! "Pleasure," as a dominating influence, as our great bard says, is of those spirits which:-

" . . Lave ears more deaf than adders to the voico of any true decision."

But to return to the general question. The Jubilee of the Volunteer Force is approaching, and in this year 1905 no one can tell what its future is to be. The only thing that seems cortain is that a determined effort is to be made to cut down its strength by$50,000 \mathrm{men}$; till a few weeks ago we heard it was to be 80,000 . For what good purpose this is to be done, it is very difficult to see. At a time when it has been made manifest in South Africa, and is being made still more manifest in the Far East, that war to-day means the assembling of enormous forces, which are to the armies of Napoleon and Wellington as an elephant to a rat, the greatest effort of Statesmanship and of -Army Administration for the better defence of the country is to reduce a quarter of a million of men voluntarilv enlisted to 200,000 . The pretence is of course that there is to be some wonderful scheme by which the 200,000 are to be much better than they were before, although how they are to be better no one knows. For it is quite certain that the scheme originally propounded for forcing Volunteers to do compulsory continuous training in camp, whether it was consistent with possibility or not in view of their civil obligations, has fallen through, and will only he mooted again by the tinkers of Pall Mall in some modified form, which will take the compulsory element out of it. To order Volunteers to compulsory duty for a fortnight in time of peace is quite inconsistent with the very basis of their service. It would subject employers of labour who allow their men to join the Force to a severe and exceptional tax. It would cause thousands of men to be compelled to make their choice between resigning and losing their employment. It was a proposal quite inconsistent with reason. A Volunteer must of course submit to certain conditions for efficiency, but the time of year or the time of day at which the prescribed work shall be done must in all reason be left to his own commanding officer, and not dictated by an ill-informed and system-bound Department. The C.O. must be left to order his drills, and regulate his musketry and all other duties, in consistence with the fact that the Volunteer is a person whose first obligations are those of civil life, and whose duties as a Volunteer must be adjusted so that his livelihood and his contract obligations to others shall be safeguarded. And the stitable will-necessarily be different in different corps and in different localities. Surely if a man's services are accepted upon the footing that he is sacrificing of his leisure time, you are doing him a wrong if you demand of him that he shall give up the duties he has undertaken and break his contracts to serve you at times which you prescribe. I speak of course of peace time, when he has not been called to actual service, but is in the position of his first ohligation being to his civil duties and to his family. And still less reasonable would it be in the case of the professional man who has a going business, and who cannot, as a workman can do, leave his work for a time with reasonable confidence that he will obtain other employme $t$ when he returns. What was 
the consequence of the promulgation of this extraordinary idea of clictating a fixed period of continuous service to the Force in the startling Order in Council? The professed aim of proposed reform being to get a better class of men, the immediate effect of the Order was to deplete those corps which mainly consisted of men of a better class, and which in the Mletropolis had for five and forty years cheerfully given more service than the Regulations exacted. Let me give you a few figures. There are perhaps no corps in the kingdom more representative of middle-class life than the four I name:-

The London Scottish.

The London Irish.

The Queen's Westminster.

The Artists.

These corps, at the time when the new scheme of compulsion was mooted, numbered respectively $1,100,1,382,2,000,1,100-$ in all 5,582 . No sooner were they made to understand that there was an intention of exacting duty from them as a condition of service at a time and place and for a duration fixed by authority, whether their civil engagements would be interfered with or not, and that the alternative was financial ruin, than these numbers fell to 550, 660, $1,000,500$, or a net loss at one fell swoop of 2,872 of the flower of the Volunteer Force-men of higher intelligence and education, and finer plysique than most of the urban corps of the country. I cannot -doubt that our rulers at Pall Mall, if they made any enquiry, before they made their announcement, were well informed by those who could speak from knowledge of what its consequences would be; but they always know better. They never realise that the Volunteor not only may, but must; judge for himself as an individual whether he can or will continue his service under conditions dictated to him.

But then it is said, we consider this to be necessary for efficiency, and therefore we must insist upon it. Good. The Voluntecr admits . that authority is entitled to formulate its demands; but it is vain to call hirr unpatriotic and to denounce him as a bad citizen if he announces that the conditions are such that he cannot undertake to fulfil them. He is doing voluntarily and without any return for it what is no more his duty than that of every able-bodied citizen. When conditions are prescribed to him he is surely entitled in the exercise of his liberty to consider whether he will volunteer or continue to volunteer on such couditions. Time and time again has the Voluntecr given up lis only week's holiday in the year, tenerce conjugis immemor in many a case, to submit to training. If he says, "I cannot give a fortnight at the prescribed time of the year without an undue strain on my family relations, and it may be with a loss of my employment," in what sense is he acting unpatriotically? Surely the patriotic man is the man who gives what he can, at those times when he can, and the unpatriotic man is the man who gives nothing. If those who give what they can are not worth having on that footing, then I say again, disband them and face the situation. If you are not prepared to to that, then you must take what service the Volunteer can give you, as regards day and hour, of which he is and must be the judge, whether the WVar Min ;ter and his advisers like it or not. It is his own local commandin officer who must judge of the when and the where the prescribed quantity of training can be given. Without 
reasonable elasticity the working out of a Volunteer system is impossible. Rigidity must result in collapse.

But then the cry is that the Volunteer is too poorly trained to be of any use. It is rather amusing. One Cabinet Minister says this with emphasis, and another proclaims the "Rifle Club," without any military training at all, to be the hope of the country. "If once," he said, "you impress upon him"-the citizen-" that the defence of the country is not the business of the IVar Office or of the Government, but the business of the people themselves, lcarning in their oun parishes the practice and accomplishments which will make them formidable in the field, you will then have a defensive force which will not only repel the assailant if lie comes, but will make the chances of that assailant so bad, that no assailant will ever appear." And a Minister in the War Office Department announces that the Government looked upon Rifle Clubs as the best rnaterial out of which to form an Army if emergency should arise.

Thus, on the one hand, those who have been training to serve the country, are told that although they have drill training and regular musketry regulation instruction, unless they go into large military camps for considerable periods, and at times prescribed and forced on them, they cannot be of any use; and, on the other hand, we are told to rely upon the people acting independently. of Pall Mall, and His Majesty's Alinisters, and learning what is needed for tho national defence "in their own parishes." A defensive Force is to be begun to be formed out of "Rifle Clubs" after emergency, and not before it. What a splendid Bab Ballad W. S. Gilbert could turn ont, without in any particular misquoting these deliverances, of our great ones. In order to encourage the people to devote themselves to the country's defence, those who have already done so are to be insulted by an order for disbandment to the extent of 80,000 , now brought down to $50,000 \mathrm{men}$, for no conceivable purpose that can be suggested, except to cut down the estimates by $£ 350,000$. One would like to know what will be the feelings of the population towards devoting themselves to "learning in their own parishes the practice and accomplishments which will make them formidable in the field," when they see that those of their young men who have done so in the-only way in which they have been asked to do it, are to be subjected to the insult of being stripped of their uniforms, and made to send their rifles into store to go back to the Government armoury, upon the footing that all they have been taught by Army adjutants and instructors is of 'no use. They are not likely to be soothed by the statement that in emergency they can get back to service through a parish organisation, by the people carrying out what is their business and not that of the War Office or the Government. Of course, it will bo said that the 50,000 will be selected from the least efficient, from corps and companies that are feeble in strength. This is the scolding clergyman over again. Those, who in spite of lethargy around them, have held to their posts and done their best not to let the Service fail in their district, are to be rated as useless fellows, and sent to the right about, because others stood by idle. The men who have made sacrifices and stuck to their work in adversity are to be dismissed to carry into thcir little circle a bitter feeling of resentment, which will rankle long, and make the service of the country to be a thing which is known as bringing with it the sting of contempt. But worse than this; it is in outlying places, thic 
thinly populated districts, that most of these supposed weak lambs for the slaughter will be found. And it is just there that the strongest bodied, hardened, and sound men aro found, the very men most wanted when endurance of body is called for-the first and most important element in the foot soldiers' suitability for service, and who ought to be kept together, although it be in small numbers, and with a modicum of drill. And these men, the very best material for a country's defenco that can be found, you are going to thrust out of your Volunteer defensive service, because they, with their limited opportunities, cannot learn everything, while the rest, who have never done any service, are told that parish rifle clubs will be so mighty a defence that they will frighten an enemy from off our shores. A Inore fatuous policy for cheeseparing saving was never perpetrated in the history of a nation. Surely something more consistent and sensible might be expected on such an all-important subject as national defence.

But then it is said that they are not needed, that 200,000 is quite a sufficient number for the defence of the country. It is hard to believe that such a statement can be the result of any but the most surface reasoning. If it means that what is left of 200,000 men, after they have been depleted by the great losses which have now to be faced in modern war, and which, in the case of a death struggle to prevent a successful effort at destruction of our national power, would not be small, then I take leave to say that there is no man in Pall IIall who could work out a calculation such as that which would be worth serious consideration for one moment. If, apart from so great an issue as national existence, it means that 200,000 Volunteers are sufficient to deter any foreign foe from attempting to land a powerful raiding force on our shores, then the Volunteers would consider the view to be highly complimentary to them, but scarcely consistent with the report of a recent Commission. Tho logic would be rather funny which said "we have a Force of 250,000 Volunteers, but neither their musketry nor the tactical training of the rank and file would enable it to face, with prospect of success, the troops of a Continental Army," and therefore now, when that is its condition, we will diminish its strength by $50,000 \mathrm{men}$, as 200,000 such men are quite sufficient for defensive purposes, and will leave it to the future to show whether in our 200,000 retained we have a Force that can be trusted for the national defence. Since the days of Ifushai the Archite - who, by the way, spoke to mislead the Government in esse, and not to aid it-no more preposterous position was ever taken up by the military advisers of a nation. The authorities are making believe-either consciously or unconsciously, - they may take their choice of imputations, - towards the development of an efficient national defence, of which a restricted number of Volunteers are to form part. What apparently they propose to do is to make a show before the eye of the public, by introducing far-reaching alterations, cutting down this cadre by so many men, and ordering those that are left to do more, whether they can do it, or are willing to do it, or not, and nourishing before Parliament and the country the trite maxim that it is better to have a smaller force of thoroughly efficient troops than a large Force which is less efficient. Thus they excuse the squeezing out of the Volunteer Service of one-fifth of its present strength, while they ask that it be assumed that attenuated numbers must bring about greater efficiency in those that are left, without there being the slightest ground for so believing, and in 
direct contradiction of the advice of those who are in the most intimate touch with the Volunteer, as the denizens of Pall Mall have never been, a few honourable individual cases excepted. The "what ought to be" is made a sufficient ground for drastic changes, when a sound discretion would lead to the consideration of "what can be," as the first question for solution, and whether assuming things to remain as they are, it is possible to say that more "can be" than now is. It is futile to take action to change "what is," until it is certain that the change is practical and practicable, and will bring "what is" nearer to "what should be." What those who now enter the Volunteer Force seek to know is, whether their services are desired at all, as citizens who are willing to make some sacrifices which others will not make-sacrifices of time and labour, and of social and family life, at the nation's call? Are their services desired because they are looked upon as real services, for which the nation should be grateful? Or are we to understand that we have been accepted to form a sort of buckram army, stuffed figures on a hill-side, to hoodwink an ignorant public, without hope of deceiving the Secret Services of other nations? Are the Volunteers to stand between the Government of the day, whatever it may be, and the problem of how to get out of the Treasury what is neoded to constitute a real national defence Force, with the certainty that whenever they propose the necessary expenditure, they will be turned out of office for burdening the tax-payer with the cost of "bloated armaments," the usual clap-trap which makes rulers afraid, and leads them into the bye-lanes of temporary party expediency.

The question may be put in a very telling way by an illustration. If all the Voluntecrs in the country were to exercise their undoubted peace-time right upon the 1st day of next month, and to send in their resignations, which would take effect on the 14th of that month, what a howl of indignation at their unpatriotic conduct would go up from those millions who have never shown a trace of national defence patriotism at all. But the situation would then have to be faced. If this happened, does anyone suppose that the public would be put off by any War Minister or any Committee of Defence, telling them to keep their minds easy? Does anyone suppose for a moment that the steps which would be held to be necessary, and would be demanded from the Government, to put the country into a state of defence, would not cost ten times as much as is now expended to meet the outlay connected with the Volunteer Force as it exists? And no doubt by paying for it they would get something letter. But they would not only have to pay for it, that would be their least difficulty. They could only get it by compulsion. Enforced service would become a necessity. Now, the Volunteer has a right to ask what is the view that is taken of him by those who now make use of him-to ask whether he is looked upon as a convenient makebelieve, a paper Army to flourish before our own and other nations, deceiving ourselves and deceiving nobody else, lulling the public into a false sense of the security of the national stronghold, and fending off conscription with all its distasteful aspects to the possible conscript, and its certain unpopularity with the tax-paying citizen. If the IVar Office, after another Commission or two, will only come to a definite conclusion and frankly express it, they need have no fear that any Volunteer will resent a decision that some more efficient means shall be providęd for national defence than the Force 
can give. If no Volunteers, and a congeries of independent Parish Rifle Clubs is a better provision for national defence than what we have at present, tell us so, and we will cheerfully withdraw from a false position. I have been associated closely with the Volunteer Service for five and forty years, and I know that the feeling of all good Volunteers has always been, and has been often expressed, that if their existence was to be held as an excuse for weakening or starving the Regular Army of the Crown, they would at once leave a Force whose existence was being, in the supposed case, exploited for the illegitimate purpose of flourishing before an ignorant public economical budgets for party and therefore for unpatriotic ends. They would unliesitatingly support the viow which the late Duko of Cambridge, when Commander-in-Chief, expressed with emphasis:"That any step taken as regarded the Volunteer Force, which might lead to a reduction of the Army, would be disastrous."

And this leads me to say that when we Volunteers are told that we are not properly trained and equipped for service, we would most heartily rejoice if it were easy to believe that it could be truthfully said that our part of the Forces was the only one of which the statement could be.made. Have we not seen very strong indications of late years that there is much to find fault with in the training of our Regular Forces? Admitted that in mere drill, the externals of military training, they may be able to exhibit that greater "steadiness on parade" which, though undoubtedly a part of military fitness, is only a part, and by itself but a subordinate part of military efficiency. That is, I. know, a frightful heresy, and I admit it would be, if the be-all and the end-all of military training were a good march-past. But I think we have outlived the belief that closo work, after the pattern of the days of the Duke of Marlborough and Prince Eugene, is still the talisman of military success. We have had lately a struggle with an enemy to whom the march-past was as strange as integral calculus, and in which we did not always slow to advantage. I for one can only think and believe that the defeats and surrenders of the first six months of the South African campaign were not the result of our Regular officers and men being trained in such a way as to fit them for war under modern conditions. Either the system was bad or the training under the system was bad, or the officers and men were bad. The ordinary citizen, who knows his fellow-countrymen, believes and will continue to believe that it was not the material that was at fault, but the failure so to handle the material in peace time as that it should be at all times ready for war under modern conditions. Then again, the marksmanship of the Volunteer is criticised. Well, it is not so many years ago that in the Isecture Hall of this Institution I heard the opinion of the shooting of the Regular soldier from so good a representative of the real military man, viz., Sir Henry Brackenbury. Here are his words, spoken after his return from the Soudan expedition for the relief of General Gordon. After giving the highest praise to the general qualities of the British Infantry soldier, he said :-

"But there is one thing, Sir, I regret to say, and that is, that they cannot shoot. Nothing struck me more, perhaps, after our little figlit at Kirbekan, than to see the whole faces of rocks, as big as the side of this room, spattered with bullet marks, that could not possibly or conceivably 
have gone within 20 feet, 30 feet, or 40 feet of anyone at whom they could have been aimed."

I quote this only to show that when people imagine that it is only among Volunteers that there are serious deficiencies in fitness for service, there is another side to the picture.

And as regards matériel, of war, low do we stand? The Department which is responsible for the national defence on land is found to have been for years behind the world in the artillery arm, and we have nothing between us and a foreign foc but the promise that we sliall in course of time have guns that can hold their own against our enemies, if they will only give us a few years to get them; while as regards the small arm, we are once more engaged in listening to a Babel of experts, condemning, or at least accusing, one another.

One thing is certain, that if history repeats itself, it will be a long time before our Royal Artillery have the guns they ought to have. For how many years did the Government mock the Voluntecr Artillery by sending them season after season to pretend to be preparing for national defence by shooting with old cast-iron smoothbore guns, about as efficient for the war of to-day as those which lie outside the door of this Institution.

Lastly, we are told that there is great deficiency in transport power in the Volunteer Force. The reason is obvious. You can get men and take work out of them at very little cost if they get no pay; but when it comes to beasts and vehicles for them to draw, it means a good round sum down. One would like to know whether the War Departinent is satisfied with what is doled out to it by the Treasury for the Regular Army. Does anyone believe that the Division-or is it Army Corps? - at Aldershot could at a week's notice move out in thorough war equipment for the road? Of course, we know it could not.

From all this it would appear to the ordinary mind that our War Minister lias enough on hand in the work of getting the Regular Army into an efficient state as an instrument of war in its training, its matériel, and its transport. The country will desire to see our regular land forces brought into a state of efficiency which will compare with that of our sea force before it will have any confidence at all in the powers of our War Department to provide it with a really efficient home defence. In the meantimo, it is worth considering whether there is wisdom-or not rather folly-in discouraging in any corps or in any place the development of such military efficiency as can be obtained in reason from any man of sound body and mind who offers to submit himself to training and discipline, so far as is consistent with his primary dutics in life. Will any sensible man deny that a number of rough-hewn blocks are nearer the finished article than the stone lying untouched in a quarry-face? And when it comes to war, then the old saying that "time is moncy" has its truth demonstrated in the bleeding of treasuries and the welling away of a nation's life. In such a case a depleting of the Voluntecr Force by $50,000 \quad m \in n$ to save two or three hundred thousand pounds may cause an expenditure of millions and an unnecessary loss of thousands of lives, even if your military operations are ultimately successful. It has been so and will continue to be so whenever the nation is face to face with the exigencies of a great struggle for existence, until the question of mational defence is tackled in a practical manner. 
We who so think may have little hope that Ministers and Defence Coinmiltees can be brought to look at matters from our point of view, but feel that our testimony must be spoken now, "whether they will hear or whether they will forbear."

Colonel Hugn Pearse, D.S.O. (late Commanding 2nd Battalion East Surrey Regiment) :--Lord Kingsburgh quoted several officers, chiefly commanding divisions in South Africa, as to the value of the Volunteer Service Companies, and they all naturally spoke most highly of them, and $I$ think perhaps possibly a word or two from me might be acceptable, as I had the honour of commanding a battalion in which one of these Volunteer Service Companies served. The company which came to my battalion was an extremely fine one in physique. It was also very well trained and well officered. It did not fail in any particular. But what I desire to say is that its great merit was something that has not been mentioned by the lecturer, namely, the most important quality that any soldier can have, whether ho is a Regular, or a Militiaman, or a Voltunteer, and that is, great earnestness and patriotism; and the men I had showed that quality very prominently. Every one of them had sacrificed a good deal to come out, and they did all they were asked to do. They were only asked to servo a certain time, at the end of which thes went homo. 'Their one anxiety was to have some casualties in the company. That was a spirit which cannot be too highly commended; it is the spirit which has enabled the Japanese to do the wonders they have done in the present rar. Although it does not become an officer on the active list to discuss the desirability of any step taken by the War Office with regard to reduction or non-reduction of any part of the National Forces, I should like to add my humble testimony to the great value of the patriotic spirit of the Volunteers; and I think everyone will agree that if you have a good body of men with that spirit you cannot have too many of them. Nothing but financial considerations would suggest for a moment that the numbers should be reduced. There is one point in which $I$ believo the Volunteers could be improred as regards their fitness for war, and that is not a matter that solely affects themselves, but one that affects tho nation-the want of gymnastic training when boys. I believe that if every boy in this country receired a gymnastic training-not necessarily a rery exacting one-while at school, which is the best period for such training, he would learn his drill very much more easily, and he would be more fit to endure hardships on active service.

Colonel H. Beturve Patrox, C.B. (Brigadier-General Commanding Gloucester and Somerset Brigade):-Throngliout a long service in the Auxiliary Forces, dating from the year 1861, when I left the Army, it has struck me on many occasions that just before the Army and Nary Estimates there has been always more or less an attack made on the Volunteer Forces. Over and orer again, just at that particular time, it has been said that there is little or no fear of invasion; and I imagine that is the soletreason why we Volunteers exist in the country-that is to say, to be ready to repel an invasion. They have carried this to such an extent that the whole British public were told tho other day, through the Press, that it was impossible eren for a dinghy, containing five men, to land in this country. If that is the case, what is the use of maintaining eren 200,000 men to repel that wonderful dinghy with its five men in the event of its endearouring to land? I think we might rery safely leave the repelling of such a force to the Village Rifle Clubs. There was an 
illustration in the late manceuvres in Essex. Unfortunately it was one of the few mancurres during the last 30 years that I have missed sceing. I conld not be present; but I was told it was a beautiful sight to see transport after transport dramn up in the most precise manner, escorted by stately ironclads, flanling and protecting the landing; and that during the time it took to land these picked troops from those transports, had tney really been an enemy, before morning there would have been nothing seen, not even a ripple on the surface of the water where these magnificent ironclads and the transports they escorted lay. Why? Because we had torpedo-boats on either flank lying in adjacent harbours, and under the cover of the night they would hare pounced upon ironclads and transports alike, and before norning they would have been all sent to the bottom, and there would not have been a single vestige of cither transports or ironclads to be seen. That is a rery pretty story, good enough for a picturebook; it ought to have been illustrated in a "penny dreadful." I do not think that foreign admirals aro quite so accommodating as to come over here and allow their ironclads to lie off our shores like ducks with their heads under their wings, and be pounced upon by torpedo-boats and scnt to the bottom without firing a shot. I do not think such a thing is at all likely. The experts-the men supposed to have the best opinion as to what is likely to take placo-express the riew that invasion is impossible; but it is possible that a raid of three thousand men might be made upon our shores. With regard to the three thousand men, I have the same opinion as I had with regard to the crew of the dinghy. Why is it necessary to keep up 200,000 Volunteers to repel a raid of threc thousand men? God bless my soul, we should not want any ammunition; our bayonets on a dark night would be quite sufficient to give them a swimming lesson, and they rould be off as soon as they came. With your permission, Sir, I will give you my rersion of how an invasion might talse place. A war with tro or more porrerful nations combined, with efficient Navies, might take place, and as soon as that war occurs just imagine what will be the demands upon the British Nary. No man living has greater admiration for tho Navy than I have; but just think of what it would have to do. The $\mathrm{Navy}$ would have to escort our Regular troops, form strong escorts to take them to the country wherever they happened to be required. The stercotyped place is the North-west Frontier of India. Another thing they have to do is to guard our food supply. I am one of those mho think the food supply of this country in a war between two or three foreign Powers would be much more serious than this country is inclined to believe. I think if the starving nultitudes, out of work, could not get food except at exorbitant prices, there would bo very probably a revolution in this country. A third demand on the Nary would be to fight battles, squadron to squadron. Then, in addition to defeating the big squadrons of the enemy, they have to encounter those deadly enemies the submarines, torpedoes and mine-fields. Then, when our Regular Army had all gone abroad, as it did in the South African War, followed by our Militia, of whom I have a very high opinion, would bo the chance of the enems. I have nerer served in the Militia, but I have seen the Militia at nancuvres, wet through to the shin, coming along whistling, with their heads up, and I have come to the conclusion that if only those men are taken care of, well officered, and done justice to, the country may rely upon it that it can easily be made a magnificent Force, and one that would create a very fine second Line for tho Regular Army. This of courso is provided they aro treated properly. I will not take up your time by alluding to what $I$ consider is the proper treat- 
ment. Now, when the Army has gone and the Militia has followed them, we should be very likely, according to our present organisation, to be loft in a sad plight. We should bo left without any guns, as we were during the South African War. There is a very distinguished officer present at this meeting-I will not mention his name--who asked me in my tent on Salisbury Plain in 1900: "How many batteries of artillery de you think re have now left in the country?". I liad then 8,000 Volunteers under my command within a month. I said: "I hare not the least idea." The distinguished colonel said: "There are six batteries of artillery only in all Great Britain." If things are going on the same now as they did then, the invasion I have spoken of might be a far more successful business, and instead of a raid of three thousand men, we might have an invasion of 100,000 men or more, and then it rould become a question of what would happen supposing the country chooses to allow the Voluntecrs to be left without organisation. Now, what is to be done to prevent that? I think the remedy is very simple. Treat the Volunteer Force as a separate and independent Army for home defence, and for home defence only. Let us send contingents abroad by all means if we get the chanco-as provisional brigades, as I suggested for South Africa-and I daresay wo should send a lot in the event of war; iet the Home Defence Army bo organised in mobile columns-easily concentrated, forming the arc of a circle round the invaders by rail. Let us have everything all ready : mobile columns of about 10,000 men of all arms, commanded, if possible, by Volunteer officers themselves, and, if impossible, by ex-Regulars, who will remain with the Volunteers and with their Staff, and that will ensure that we shall not bo left like babes in the wood, without the officers of the Regular Arny commanding us as scon as the war breaks out. Naturally, every good officer's service would he required abroad; but we can still have those officers who have had a thorough training with the Regular $\Lambda \mathrm{rmy}$, and to my certain knorledge many excellent Volunteer officers. There is only one more thing I will allude to. In the event of a war such as I have mentioned we should securo the services of a Volunteer Reserve. I know something about the Volunteer lieserve. Tears ago I got 600 men formerly of the battalion I commanded to sign a certificate to the effect that they would come up in the event of war, and without any pay they rould do three drills a year or more, and that they rould fire so many rounds at the range. Amongst those 600 men the smallest man was 5 feet 8 inches, and the tallest 6 feet 7 inches; $I$ never saw finer men in my life. I maintain if this country would only entertain the idea that the Volunteers should be treated as an Army, it would be a great success, and any amount of officers would be proud to belong to it. If it is to be a success let them hare a Reserve behind the Volunteers of 100,000 or 150,000 men ready to fill up the gaps as they occur in the event of our being attacked, or for garrison duty.

Licut.-Colonel T. H. B.ris, K.C. (late I8th Middlesex V.R.C.) :-I am permitted by the Chairman to say a few words to you, and I congratulate nyself, and I think we may congratulate ourselves on having the Right Hon. Sir J. H. A. Macdonald as a lecturer to-day. He has mentioned tho date 1859 , and $I$ well remember it. I think he joined a year after that date, but $I$ joined in that very year.

Lord Kingsoungin:-I joined in April, 1859.

Iieut.-Colonel Bariss :- Then we are contemporaries, and it gives me very great pleasure to find that is the case. I have always regarded 
with the greatest respect and esteem Lord Kingsburgh whenever I saw his name mentioned in connection with the Volunteers. He is a man of remarkable legal intelligence and military knowledge, and we must all admit that he has brought before us to-day information of the greatest practical value. In the précis it is said that the Volunteer movement had its origin in patriotic feeling. I remember very well indeed in 1859 what caused that patriotic feeling: it was the threat of the French colonels to invade England. I also remember, if my memory serres me aright, that it was Louis Napoleon who advised us to get a Volunteer Force. Having regard to the entente cordiale being so great now between France and England, I can comparo with pleasure the present time with that of our relations in 1859 . As an old Voluntecr officer $I$ joined in the ranks and rose from private to lieut.-colonel, and naturally have had some experience; and I believe that what kept the Volunteer movement from being popular was the Government. The Government of that day was afraid of entrusting arms in the hands of the people. I was the senior churchwarden in the parish of Paddington during the Crimean War in 1851-55, and I remember we offered our services to the Government, and they would not accept us. Aftermards they accepted, but simply through the force of public opinion, and then the gallant colonel and myself joined. So that you see it was the threat of invasion. I think I am quite in order in saying that it is not only the patriotism but the loyalty of the Volunteers. The Government were rather afraid of their loyalty; they were afraid that they might become tools in the hands of the people. But they are a body remarkable for patriotism and for loyalty. There is one remark of the lecturer which I cannot quite agree with, and that is with regard to the decrease of the Forces. We all know that what we want is efficiency. We do not want numbers so much as efficient men, and everything that we can do to make them efficient is desirable. Therefore $I$ am one who would see the Force reduced in numbers, but I would not have one penny less, giving the money to those who remain, making them more efficient. 'They should not be one penny out of pocket, and if they give their services they ought not to be anything out of pocket. I should like also to seo commissions given more freely in order to attract officers. Another remark made in the paper is that a full cadre of efficient officers is of importance. No doubt that is so. The busiest cirilian is the best officer, and our lecturer is a specimen. $\Lambda$ man can always find time if he has a will, and I beliere there would be the will to do it, but they do not sco the imminent necessity. I should be delighted to see the Force efficient. In conclusion, I would simply say that if there is an invasion it will be sudden. It will be impossible to call our Militia together immediately; but wo can always call the Volunteers together at once, because they aro on the spot!

Colonel M. B. Penrsox, C.B. (late 2nd Middlesex R.G.A., Vols.):-I am sure we have all listened with the greatest satisfaction to the lecture that has been delivered to-day by Lord Kingsburgh, and every word of it, I think, can be endorsed by us. There are tro aspects of this question : the first and the broader aspect is as it affects national defence, and that 1 think may be left to Parliament and public opinion. The other aspect that appeals to many of us who have served for very many sears in the Volunteer Force is as to how this proposed reduction in the Force and the present regulations will affect the Force itself. In November, 1901, when the new regulations were brought out, I for ono looked upon those regulations with the greatest horror; I ras a pessimist, and I could 
quite see that they would havo a very injurious effect upon the Force. In consequence of that I may take some credit to myself for having got them altered, and haring initiated the great meeting of commanding officers in the theatre of this Institution in January, 1902, the result of which was to get a Departmental Committee of the War Office appointed and those unworkable regulations so far altered that instead of each company of the Force requiring at each drill to put 25 men on parade before they could count the drill at all, the present regulations were substituted, and they are much more workable. But we did not succeed in getting the compulsory camp regulations withdrawn or greatly modified. When we had an interview with tho Secretary of State and the Commander. in-Chief at the War Office we pointed out very strongly that the effect of compulsory camp would tend to a rery great decrease in tho numbers of the Force. I renture to think that my riews and those of many of my colleagues were justified. We have seen many of the best regiments in the Service depleted, and some reduced to half their original strength. lou might take one notable instance: that fine regiment the London Nifle Brigade, which is now reduced to just over 500 men. I have seen that regiment 1,100 strong on parade; and it is grievous to think that regulations having such an effect'should have been passed or have been continued when the disastrous effect was shown. With regard to the numbers of the Volunteer Force, it is not material to us individually whether the numbers are 200,000 or 300,000 , but those who are acquainted with the interior economy of the Force know perfectly well that if each battalion or regiment is deprived of a certain number of the men, each unit is on the road to hopeless bankruptcy. There may be a few which keep up their numbers, and those corps which keep up their numbers are mainly those composed of men in daily employment who, as the lecturer saicl, can cease their cmployment with a reasonable prospect of going back to it; but a number of regiments that have been affected seriously are those containing men in permanent situations, who cannot ensure a fixed period of the year to be able to get leave from their employers to attend camp. The very foundation of the Force is that it should be composed of two classes: efficients and non-efficients. What does it matter to the Gorernment whether a corps contains a certain proportion of non-efficients, provided no capitation grant is allowed for them? It is only claimed for those who fulfil the conditions of efliciency, and those conditions must bo something that the Volunteer Force is capable of fulfilling. I think wo must all agree with the lecturer upon that point. We have in times past, under existing conditions, incurred very large obligations. Wo havo erected hendquarters and entered into financial obligations which are still continuing, and if the Force is deprived of the necessary amount of financial support, it is perfectly certain that in the course of a very short time many regiments in the Service will become insolvent. One corps that $I$ am rery intimately connected with will, in this particular year, have its expenditure exceeding its income by about $£ 400$ or $£ 500$. Now, that corps cannot possibly go on. We are told by the Secretary of State that it was intended to spend the same amount of mones over a smaller number of men; but that will not be spent in the shape of capitation grants. The capitation grant is only for the number of efficients, and unless you have a large number of efficients it will be impossible for each regiment to be able to pay its way. Now, as to the question of the physique of the Volunteer Force. It has been stated in. Parliament that 33 per cent. of tho Volunteers were rejected. $I$ venture to say that whoover mado that statement-I think it was the

VOL. XLIX 
Secretary of State himself-cannot be aware that thero is a regulation in tho Force for physical examination on joining; erery recruit has to come up to the standard, and a very fair standard it is, too. I rould just like to refer to one little incident as showing that the Volunteer Force is not composed of inmature reaklings some would lead us to suppose. On one ocension, when Sir Henry Brackenbury was inspecting some men at a distribution of prizes-men belonging to $\mathrm{my}$ own regiment-he paused and said: "These are the men I should like to see in the Regular Service." Could there be a stronger testimony to the good physique of the Voluntecr Force than such words as those coming from such an experieneed officer as Sir Henry Brackenbury? It is a perfect myth that the physique of the Voluntecr Force is not good; it is excellent. There is testimony from experienced officers, both in peace and war, to that effect. I will take the hint of the Chairman, because I am sure we shall be glad to listen to others who would like to spesk; but I must venture to hope that the regulation as to compulsory camp will be modified, if not withdramu. It the Royal Commission, before which I gave evidence last year, I was asked the question: "Do you consider that tho Force is capable of meeting a foreign cnemy?" and I said: "As at present organised, no; but that is not the fault of the Volunteers." The organisation must be made by the War Office, and, given the proper organisation -and there I entirely agree with General Patton, that the Forco should be organised in divisions, complete in all arms and departments-given the Tolunteer Force properly organised, I belicve it will be able to meet a foreign $\Lambda$ rmy, becanse the individuals composing it are as good soldiers as you will find in any part of the world.

Major-Gencral Sir E. T. H. Hutros, K.C.M.G., C.B.:-I did not como hore this afternoon with the intention of taling an actire part in the discussion; but I thank Colonel Lonsdale Hale for having given mo the opportunity of expressing the great personal appreciation and obligation I feel towards the learned and gallant lecturer, not only for much valuable information that he has given us in the lecture, but for valuable lints during the last 25 sears. The lecturer is a typical Voluntec officer, who has contributed much towards tho knowledge and experience of the British Army of to-day. Lord Kingsburgh, 25 years ago, was a pioneer of many principles which are now a portion of the administrative system of tho Regular Britisl $\Lambda \mathrm{rmy}$. I am personally indebted to him for many valuable hints upon questions of organisation and tactics in early days. In making theso remarks as regards Lord Kingsburgh, I feel that I should only be expressing the opinion of a very large number of $\mathrm{my}$ collengues in the British Army-generals and other senior offeerswhen I say that we feel that we are under great obligation to the Voluntecr Army of the United Fingdom. The Regular Army is in a large measure indebted to the Volunteer Force for the present high standard of rifleshooting and for much of its popularity. In the early days of rifleshooting, musketry was looked down upon almost, I may say, with contempt by the Regular Army, and by many old soldiers put on one side as a sccondary obligation of military service. I am sure it is-unnecessary for me or for any other Regular officer to testify to the value and importance of the "Volunteer" morement to the Empire. It surcly cannot be necessary. It is mainly to the Volunteer morement that we ore the increasing popularity of the Army as a professional carcer for the classes from which wo obtain recruits. All know what the Yolunteer Force did in the South African War by contributing to the fighting element of the 
reginents wo led. The military forces of the Empire are dependent entirely on the roluntary system of enlistment, and it is in a large measure the roluntary forces in the United Kingdom and in the Colonies which have kept alive and promoted the military instinct of the people, and which cnabled us during the recent campaign to put nearly 450,000 men in the field. It is commonly overlooked, especially in the recent debates in the House of Conmons, that one of the most important elements which the Volunteer Force of the United Fingdom and Colonies contribute towards the military power of the Empire is in the inculcation of the spirit of patriotism, self-discipline, and sclf-sacrifico for the good of our country. Therefore, I riew personally with the rery greatest regret the necessity, if it is a necessity, of a reduction in the numbers in the United Fingdom. It is not for me, of course, or for any Regular officer on the active list, to criticise the action of the Gorernment for ono moment; but we do, I feel sure, all of us Regular soldiers, regret the necessity which there may be for reducing a Force that has contributed in the past so much to the efficiency of the military forces of the Empire, and which will nost assuredly in tho future contribute-if allowed to remain and take the permanent place which it occupies at the present moment-largely to any Aring which the Empire may call into being at a critical time in our history. I should like to add $\mathrm{ny}$. meed of appreciation also to the valuable service of the Volunteer companies during tho South African campaign. I had several battalions that had Volunteer companies as a portion of their organisation, and every commanding officer and the brigadier-generals in command of the rarious units spolic, without any exception, in the very highest possible terms of their value, their military efficiency, and their discipline. One point I would like to emplasise, is Lord Kingsburgh's vien of the Voluntecr Force and their training. The most essential points for a military force are, first of all, organisation; second, trained officers and trained non-commissioned officers; and finally, the training of tho men. I have always found in my various commands of Voluntecr troops, mounted and dismounted, at homo and in other parts of the Empire, that it is only by giving the very greatest possible latitude to commanding officers as regards the period of training and the time of training that it is possible to sweep into the Volunteer regiments the pith of the population. If rou insist upon hard and fast regulation as regards periods of training and times of training, it makes it absolutely prohibitive for the best class af professional young men to join your Force. You thereforo lose a mass of intelligence and also a plyysical value which is a most important element in any Army, and more especially in the British Army. I think, therefore, it is a great nistakc, in dealing with Auxiliary troops-if you choose to call the Voluntecrs Auxiliary troops, althougl I prefer to call them the National Force of the Empire-to bind them down by hard and fast rules and hard and fast regulations. It is far better to leave the local circumstances to dictate the periods of training and the times of training, and to give great latitude to commanding officers in that respect.

Iieut.-Colonel T. M: FAvelu (1st Sliropshire and Staffordshire R.G.A., Vols.) :-I wish to make a fer remarlss on the manner in which the Artillery branch, to which $I$ belong, is armed. At the present moment $I$ see it is said we are yenrs behind. At present we are in possession of a gun which, I think, we received 17 years ago, and which was then an obsolete gun of the Royal Artillery. I do not know whether many have seen such a thing in the Royal Artillers, but it is a very long time since 
it was there. Unfortunately we still have that gun. I suppose when the Royal Artillery get their new guns we shall have the old guns passed on to us. Only a few months ago we got an order to apply for a certain number of instruments, battery directors and other things connected with the equipment. We sent in the application in the ordinary course, and then heard from the Ordnance Store that we were not allorred them, and sc. we did not get them. . To carry on our work wo have gone to the expense of haring them made at our own cost-a rery considerable cost, too, as some of them are rather intricate instruments. Now we are going on using those and trying to learn our duties for the battery gums when we get them. If the Volunteer Artillery is really worth anything, I think we ought to have as good guns as the Royal Artillery. Let the Royal Artillery be armed first; but why should we be stopped by out-ofdate guns? I think it would very greatly assist in the corps to which I belong, both in the training of officers and men, if we had the proper guns. It is very difficult to go on year after ycar training men with obsolete guns, and trying to teach them to do work which they hare to do with tho higher gun when they get it, although they do not seem likely to get it for some time. I certainly think tho Volunteers, if they are to be continued, even though reduced to a highly efficient 200,000 instead of a partially efficient 250,00, certainly ought to have the highest class of guns. Then also there is the great danger of a mixed ammunition supply. It is bad enough as it is, but it will complicato matters a very great deal when you have such a number of ammunitions in the field. I quite agree with the remarks of the lecturer, that we are a very very long way behind, more especially in artillery matters.

Colonel Sir How Laxd Ronents, Bart. (Commanding the Iondon Irish Rifles):-I did not come here this afternoon with any expectation of speaking; but there are one or tro points I should very much like to refer to. With all the difficulties that Volunteers have gone through since the startling Order in Council of November, 1901, what I think has done greater harm and raised more feeling than anjthing else has been the statement made lately, that when we were called upon to assist the Regular Army by going out to South Africa, only 10,000 men could be got to volunteer. That was entirely a mis-statement, as was also the stated cause which led to the reduction of the number that were allowed to go. That call came upoin us as a "bolt from the blue," for after Sir Howard Vincent and others had offered whole battalions for active service and had been refused, we never expected that any further reference would come to the Volunteers. But when it did come, 370 officers and men out of about 1,100 of $\mathrm{my}$ own corps volunteered to go out. We were ordered to send a full company, and later reinforcements, but the qualifying conditions were such that hundreds were barred out; we were told that no men under twenty years of age or under two years' service, and no man who was not a marhsman, could go, and the men must be unmarricd. Of course, these terms cut down our numbers; but it is not true that 33 per cent. of the men who came forward were rejected because of their medical unfitness. We sent out altogether 207, a mongst whon we had 10 casualties. I am perfectly certain the statement I referred to has done an enormous amount of harm, and caused discouragement throughcut the Service. Of course, being allowed to enlist men at 17, a very large number of our men must be under 20, particularly as they enlist; as a rule, in most corps for a term of three or four years. There is one other thing I should liko to say: I do not think in this theatre, in 
comnection with a lecture on the Voluntecr Service, we ought to allow the occasion to pass without mentioning one to whom tho Auxiliary Forces of the country owe an enormous debt. It is not a question of politics, or of personal feeling; I mean that Auxiliary Forces owe an enormous debt to our friend the late Inspector-General, who has dono for us what no one else has done. He has adrocated our capabilities in tho most "hole-hearted way, whenever we wanted assistance, whether it was only in a war game between a couple of company officers at their headquarters, or anything else; he was ready to give his help and umpire himself. He roud do anything to aid our wishes for increasing our usefulness. I lave just come back from fivo days' outdoor exercises under him as Director at Chelmsford, and what wo Militia and Volunteer officers have learned from him will be of immense value in case of need. He is not a man who will let anything pass untested when he intends to instruct; if one of us says : "I will place a battery on such a hill, or lay out such a position," even if it is 'a mile and half of le will go to sec and criticise. He nerer allowed any of us to shirk our work, and any position we choso to talie up had to be examined by himself, and nobody else. We owo him a very great debt of gratitude, and although his official connection with the Junior Serrices has now ceased, his personal and active interests are evidently still at our call.

Colonel T. S. Cave (1st Vol. Battalion Hampshire Regiment) :-The gallant Colonel in the Chair sends me a note in which he presumes that I. am not allowed to speal. Well, so far as I know, I have not sold $\mathrm{my}$ freedom of speceh, and therefore $I$ will renture to use it for a minute of two. Several times when tho lecturer was alluding to the tinkers in Pall Mall, my gallant friend the Chairman was winking out of the corner of his eye at me. I can only say if there are tinkers there, I am sure there are tailors, and there are eren a few soldiers. Whaterer reapons may be forged there, I renture to say that one which is to reluce the numbers of the Force was not forged in the department to which I belonged; indeed, I very much doubt whether the Pall Mall tinkers are responsible for it at all. I rather think it was forged in an offico somewhat nearer this theatre-somenhere orer in the Treasury Department. I hope myself that it will never take effect, and that for a very simple reason. . It seems to me that it is based on the dictum of the Defence Committee, which has laid down as an axiom that invasion is impossible. I think that they will have to prove to us a very simple arithmetical proposition before they convince us, or me at any rate, that that is so. That proposition I should express in this way: The Nary, as I understand, is maintained at what is called the two-Power standard; now what is going to happen if three Powers combine against us? If they can prove that two is equal to three, then they will have cstablished their proposition so far as three is concerned, though even then it would be desirable to go further to prove that two is equal to four or five, if we are to be fully assured. Personally I hope that the numbers of the Force will not be reduced. I do not know where all these non-efficient men, thirty, or fifty, or eighty thousand aro to be found. If they are to be found, I should certainly like to see them eliminated from the Force; but I should like to see them eliminated from the Force not by striking them out but by making them efficient. On the whole, the propositions and the lecturer's way of putting the problems struck me as exceedingly able, and I hope that the effect of the lecture will go far beyond this room. 
Colonel W. C. Horster (20th Middlesex V.R.C., "The Artists") :$1 \mathrm{am}$ not prepared, Sir, to speak upon anything except one point, and that is the allusion which was made to the reduction of the Force as a whole. It may be that the proposed reduction is quite right from a Government point of view; but that is hardly a question for mo to criticise. It is the way of doing it that seems to me so absolutely destructive to the best features of our Service. Anybody can say the Volunteers must be reduced, but to compel good men to go out and leare in the less desirable seens to me a very curious way of doing it; but that is really what is happening. I will try and explain a little more clearly what I mean. $I$ do not consider the mere fact of my own corps, the Artists, going down 50 per cent. in three years is anything. We nay not be the best, but 1 think we aro a fairly well educated lot, and we think about things, and we read and write a little better than the average; but that is about all. We can shoot-we shoot better than the average. Those men have gone, and they will not come back, and it is all owing to these regulations. 1 cannot think regulations can be right that are doing us that harm. There was another corps congratulated by the Inspector-General about three years ago for increasing its numbers under the present regulations. They had 144 men more than they had in the year before, and that seemed a very creditable thing to him; but it was not creditable to the regulations or to the Volunteer Force. It was charitable to the men who joined. They came from an extremely poor district where they had no amusements or interests in life except little back streets. I am not exaggerating at all. The net result was that this Voluntecr Corps in the district did a charitable and national service in enlisting the men, but it did not necessarily strengthen the Volunteer Service in the manner supposed. I think the Government will discover a little Iater on that the Volunteer Force, instead of containing men of the calibre it had four or fire rears ngo, will be brought to the same level of intelligence and education as that which obtains in the Militia, and that the more intelligent portion of the Volunteer Force will be gradually weeded ont to a very serious degrec. If there is one thing the Volunteer is good for as a fighting machine it is his superior intelligence, and that part is being knocked out. 'The material will not be anything like so effective, notwithstanding the regulations as to medical examination and all the rest of it. That is one of the serious sides of the whole question to $\mathrm{my}$ mind, and all owing to some poor little regulation that a child might have told the Gorermment loforchand was, to all intents and purposes, useless in its umclastic form, and liable to seriously affect the efficiency of any scheme devised to make the best use of all classes in the cause of our national defence.

Colonel the Right Hon. Sir J. H. A. MAcoosund, in reply, said : - I have really very little to sas, because everybody has been so kind and there has been no adrerse criticism. I have no donbt that some things $I$ said might have been criticised very sererely, if we lad the right people here to do it. I cannot help saying how strongly I agree with the first speaker as regards the necessity of the youth of the country being gymmastically trained in a reasonable sense. - I fear we rely too much on athletics, under the idea that football and cricket are sufficient to keep up the physique of the masses; but I think that is a complete delusion. The vast crowds that assemble at these football matches at Preston, Swansea, Iondon, and other places-where there are 30,000 people looking on-liardly erer take any athletic exercise themselves, their greatest athletic performance con- 
sisting in pelting the referee if their orn side loses. They do not take an active part in athletics, and their mode of life is rery much against their proper derelopment. They are workmen or shopmen, and tho way they carry themselves, and the slouching way they go about with their hands in their pockets, are very much against the proper development of the chest, which is tho most powerful part of the human body for maintaining health and endurance. I remember once a recruit I had under me who could not swing his hands properly when on the march, and $I$ found out afterwards that he never probably in his life walked without having his hands in his pockets. Then I was rery nuch struck with another thing which fell from the gallant Colonel (Patton), about those men in his outlying district, the sms.lest man being 5 feet 8 inches and tho tallest 6 feet 7 inches. That is just an illustration of what $I$ wish to say about tho great danger of destroying small units in outlying places, because there you have the finest physigue, and the men are easily made into good soldiers, since they lave not the conceit of town life. If you get hold of them you can discipline them very quickly. Colonel Baylis did not agree with me that the Voluntecrs should not be reduced; he would not mind reducing them if thes were allowed to keep the money. He must have a very strong faith in the British Treasury if he thinks that any reduction of the Forces of the Cromn is not effected mainly, or to a considerable extent, for the purpose of aiding another departmentanother department, as another gallant Colonel said, nearer hore than Pall Mall. I am pretty certain that this proposal never rould have been made had there not been considerable pressure from the Treasury to l:ring down the Estimates in connection with public service. One thing was mentioned by Sir Howland Roberts, as to the number of men rejected on medical grounds. I remember in Edinburgh, at the time of the South African War, the champion runner and jumper was rejected by the medical men there, I suppose because he was short of ono tooth somewhere, so that he could not eat the biscuit! But what happened to a grent number of these men I do not believe is known at the War Office. $A$ great number of those who were rejected came straight up to Isondon and joined the Imperial Yeomanry and got 5s. a day instead of the smaller sum that otherwise rould have been paid to them. There is one suggestion I should like to make, as I am meeting a number of Volunteers to-day, and do not meet them often. I am a grent believer in power transit for nilitary purposes, and if we are to be reduced in numbers, it is a thing worthy to be considered whether we could not do as much as possible for the derelopment of the motor car in connection with the Volunteers. It would be a good thing if gentlemen would take it up in their respective districts. $A$ hundred thousand men can be transferred from the very centre of the country to any point on the coast in the course of 15 or 18 hours, and that is worth a lot of men scattered about that you cannot get there under 4 or 5 days, by first collecting them and then getting them into railway trains. Whether the people who drive horses like it or not, the country is going to be covered with motor vchicles of every hind and description. We have a Railway Corps, and I shonld like to see a Motor Corps formed, not as it is now, under the supposition that it is nerer to be used except for carrsing generals or umpires, but for transit purposes as well. I am quite certain that difficulties about transport would be remored and all difficulties about moving troops in our island would be orercome if we had a reasonably organised motor system. You could push out $30,000 \mathrm{men}$ in the course of a few hours from the very centre of England without the slightest 
difficulty, and have them all fresh and ready for their work, instead of being marched off their legs. As regards artillery, there is very little. 'Thero were only six batteries when the artillery went away to South Africa. It is of great importance to bring the gums in efficient and good condition into any position where we require them. All artillery gums for the defence of a country like this should be dramn by motor lower, and the teams of horses necessary for taking them over ground where the motor cannot go would be liept perfectly fresh, and would not be required to do long traction marches, becoming worn out and unfit for their galloping duties afterwards. There is a great ficld for thought and development there; it is a subject $I$ am taking a rery great interest in, and I may be forgiren for taking the opportunity of recommending it to my friends here to-day. I just want to make one explanation. I found I made a mistake by transposing the figures of the London Irish and the Iondon Scottish; but $I$ will take care it is put right when the lecture is published. Both these regiments are commanded by old friends of my own, and we all know that it is not their fault that the numbers have fallen away. I thank you most heartily for the way in which you havo reccived what I had to say. I am afraid I put things sometimes a little stronger than they ought to have been put. As I once said in this place, out of the abundance of the heart the mouth speaketh. Although I am no longer an active Volunteer, I still take a keen interest in its affairs, and an prepared to fight for it in the only way $I$ can now fight, namely, hy urging its interests to the utmost of my ability whenerer I get the opportunity. 